\title{
أثر إستراتيجية الشروعات في تنمية بعض المفاهيم الرياضية لدى طفل الروضة
}

إعراد

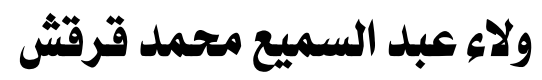

معلم أول رياض أطفال بمدارس المنصورة الرسمية للغات

إسر افـ

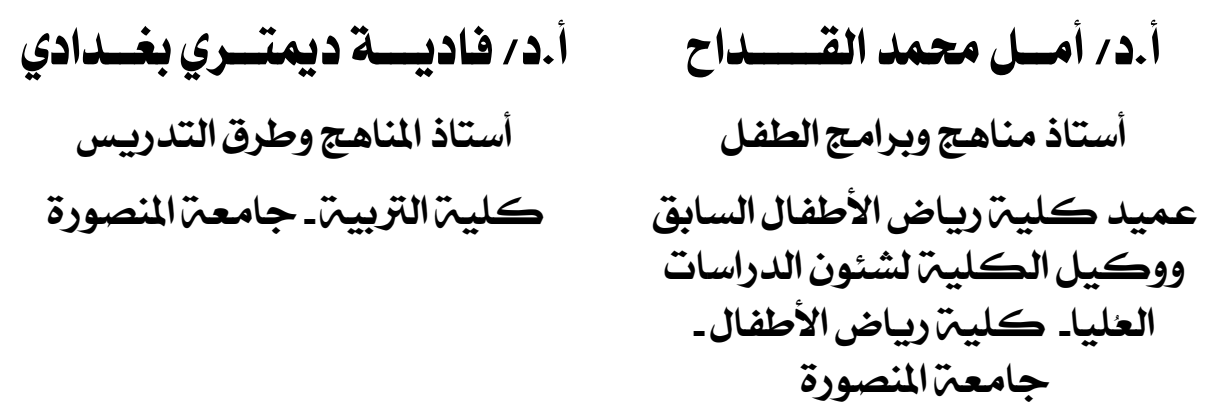

المجلت العلميت لكليت رياض الأطفالـ جامعت المنصورة

المجلد السادس ـ العدد الأول

يوليو 19. 
أثر إستراتيجية الششروعات في تنمية بعض المفاهيم

\section{الرياضية لدى طفل الروضة}

أر ولاء عبد السميع محمد قرقش*

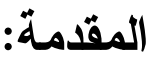

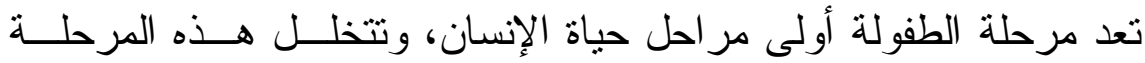

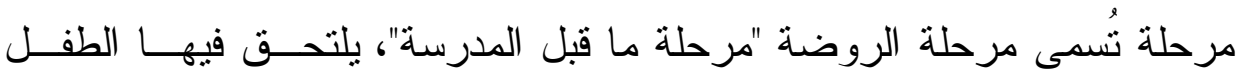

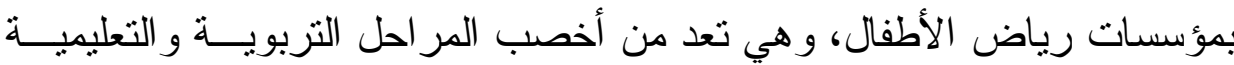
في تشكيل شخصية الطفل وتكوينها من جميع الجو انب: الجسـيمية، و الحركيــة، و الإدر اكية، و العقلية، و الانفعالية، و الجمالية، و المهارية، وذللك لما يقدم للطفل من أنثطة معرفية وجسمية هادفة ومو اقف اجتماعية، وممارسات علمية، و أنسشطة فنية وموسيقية ورياضية مختلفة.

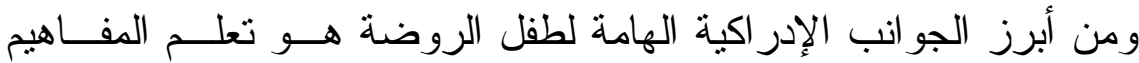

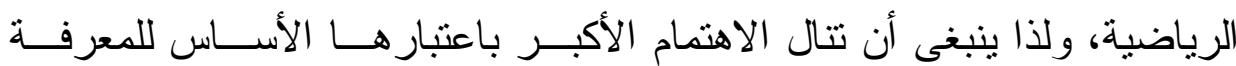
الرياضية، ومعرفة الأطفال لها تساعدهم على در اسة العلاقات التي بينها.

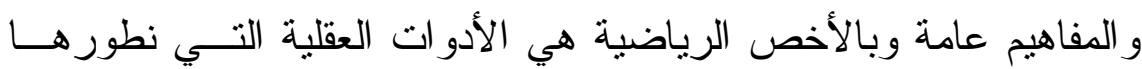
لتساعدنا على مو اجهة ما يحويه العالم من حولنا من تعقيدات ومثير ات و أثنــياء التياء

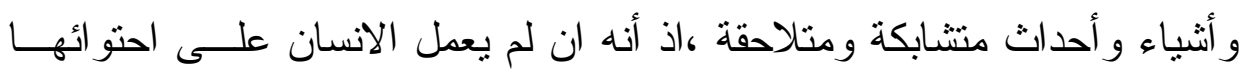
وتبسيطها ،ققد يتعذر فهمه للعالم من حوله.

* معلم أول رياض أطفال بمدارس المنصورة الرسميت للغات. 


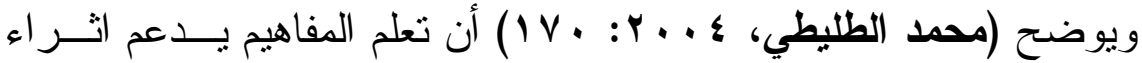

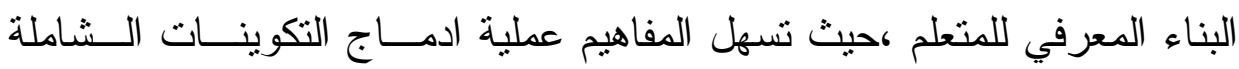
العامة وما بينها من ارتباطات فرضية في البناء المعرفي للفرد، وتعلم الدفــاهيم يساعد المتعلم الاستتناج و التطبيق و هذا بدوره يساعد علـى تفـسير المعسارف و المو اقف و الأحداث التي يتعرض لها سو اء كانت جديدة أو غير مألوفة بالنسسبة

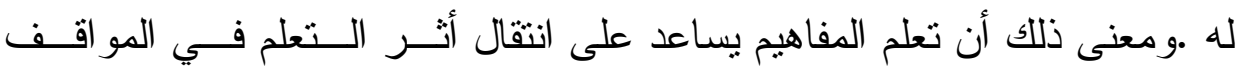

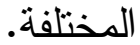

لذا تعد المفاهيم الرياضية أحد جو انب تعلم مادة الرياضيات الهامة، ولــــا

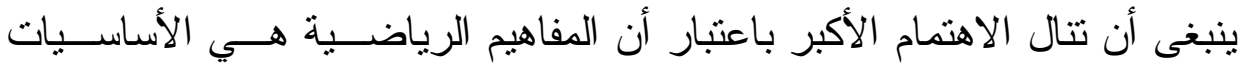

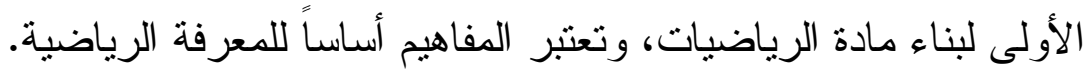
و الدفاهيم عامة وبالأخص الرياضية هي الأدوات العقلية التــي نطورهـــا

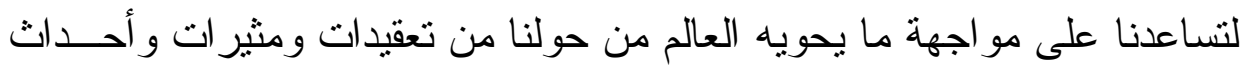

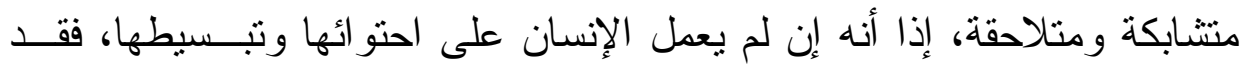
يتعثر عليه فهمه للعالم من حوله.

ومن هنا فالمفاهيم الرياضية هي الدعائم الهامة التي تبنى عليها المعرفــة

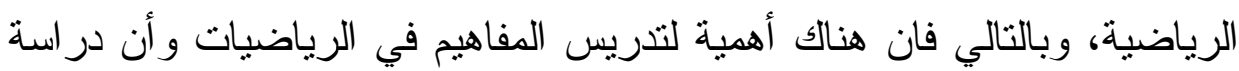

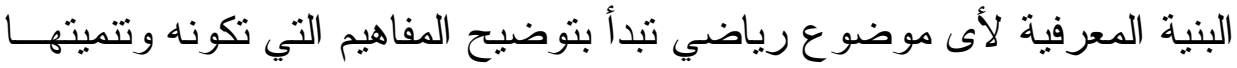

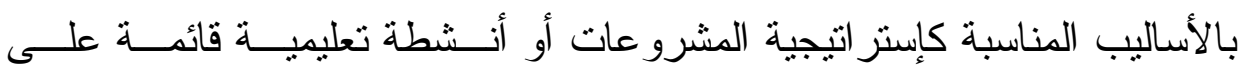

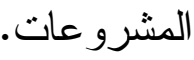

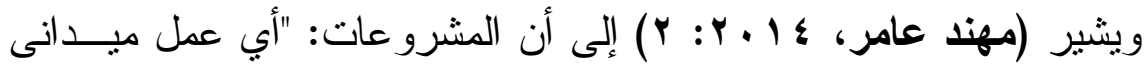

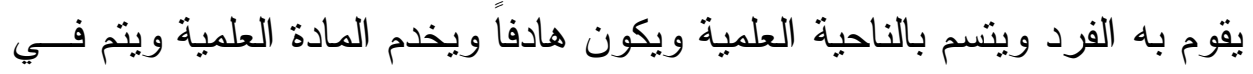


البيئة الاجتماعية ويستخدم فيه المتعلم الكتب وتحصيل المعلومات كوسيلة نحسو تحقيق أهداف محددة لها أهميتها".

كما أنه يشير إلى أن التلاميذ يقومون بتتفيذ بعـض المـشروعات التـي

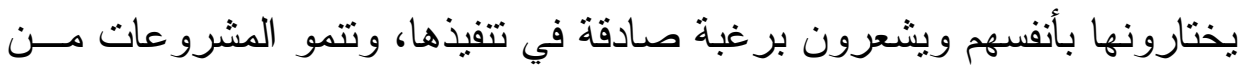

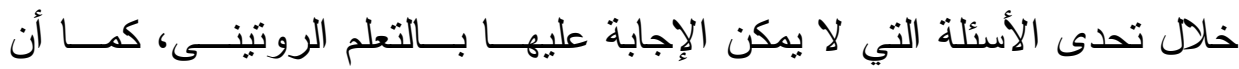

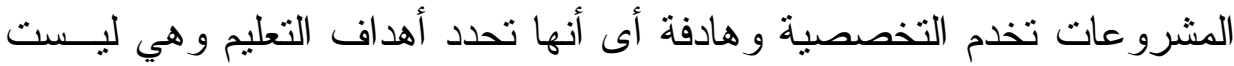

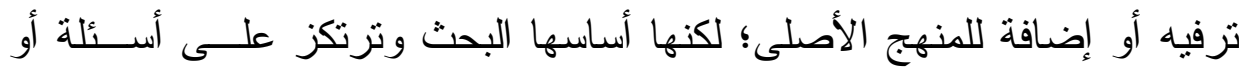
مشكلة تقود الطلاب إلى المفاهيم و الأسس في المادة التي يدرسها. وبناء علي ما ذكر فإن لرياض الأطفال أهمية كبيرة في تهيئة الطفل علمياً

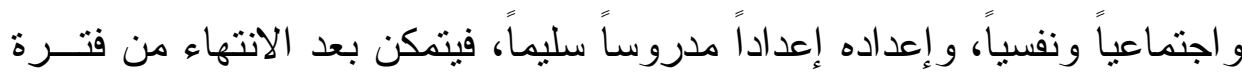

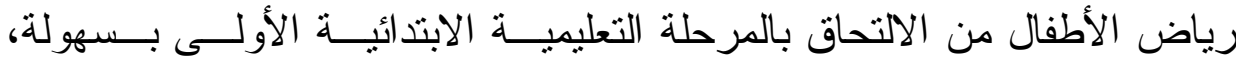

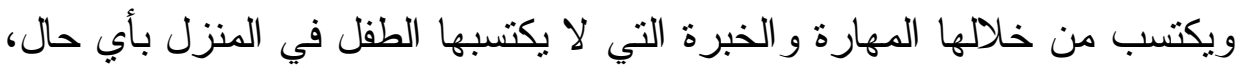

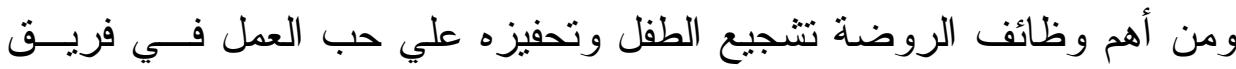

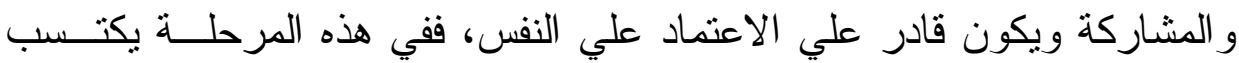

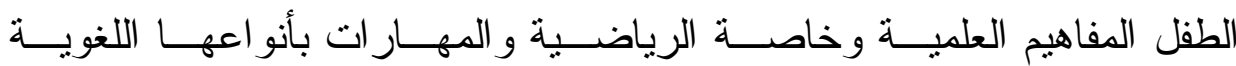

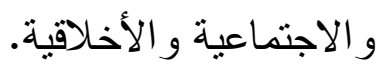

\section{الإحساس بالمشكلة: - إن}

انبثقت مشكلة البحث من خلال المصادر التالية:

1-زيارة الباحثة لرياض الأطفال ومؤسسات ما قبل المدرسة؛ حيث لاحظت

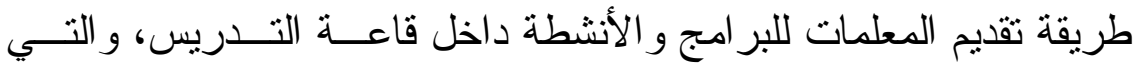

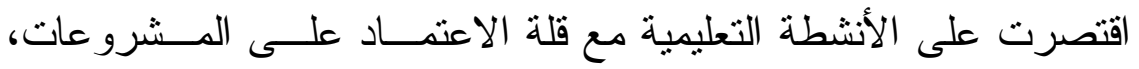


وبسؤ ال معلمات رياض الأطفال إتضح أن معظم ما يــتم داخـلـل قاعــة

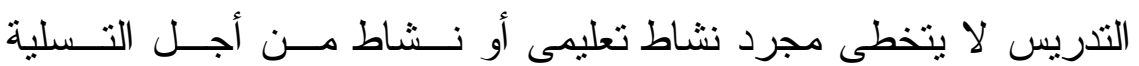

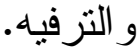

r- لا توجد در اسة تتاولت إستر اتيجية المـشروعات فــي تتميــة الدفــاهيم

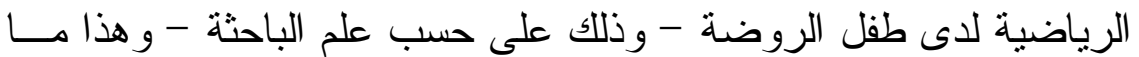
دفع الباحثة إلي إجر اء هذا البحث. لئ لرئ لذا يرى معظم المهتمين بالتربية و التعليم أن أحد الأهداف المهــــة التــي إنـي

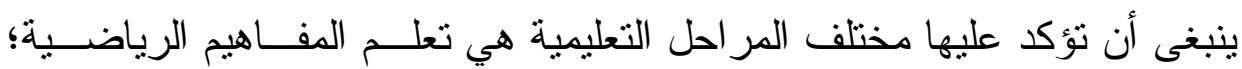
فتعلم الدفاهيم يعد الأساس لتعلم الرياضيات في مرحلة الطفولة.

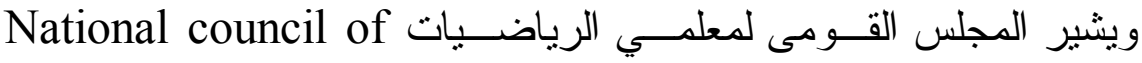
teacher of mathematics

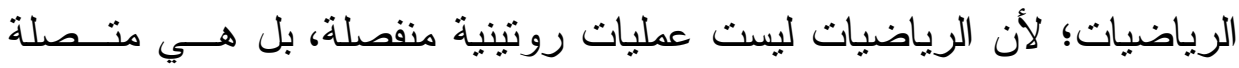

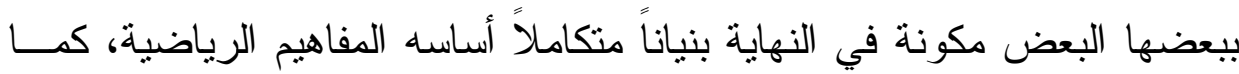
أن الرياضيات تصبح ذات معنى إذا أدرك الطفل معناها.

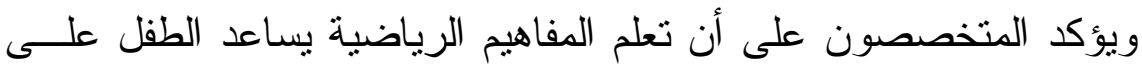

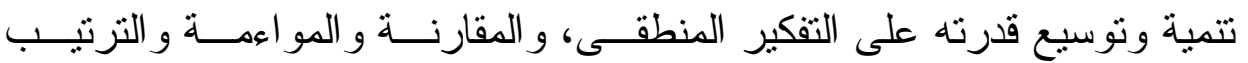

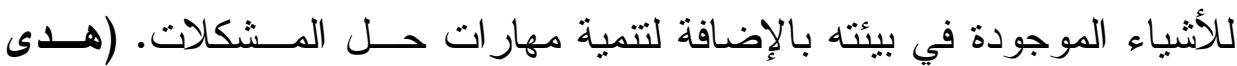

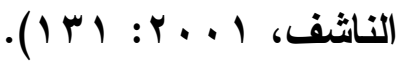

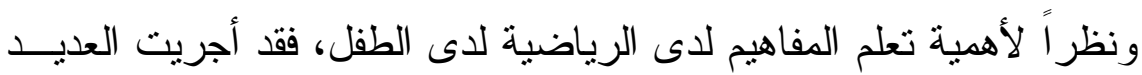

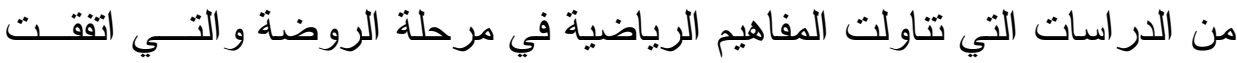

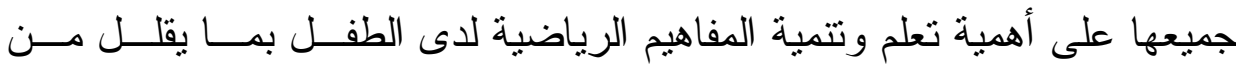
Creech, N. \& Bhavnaari, ) صعوبات تعلمها في مر احل لاحقة، ومنهــا لهميـا 


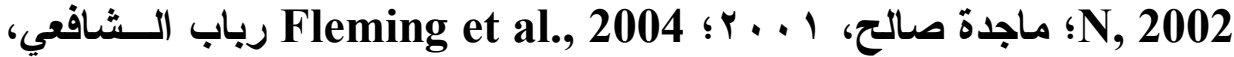

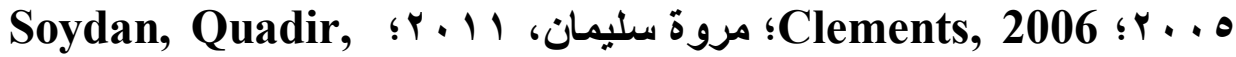

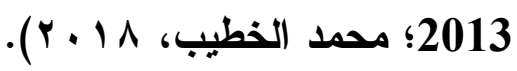
وتبرز مشكلة البحث في أن هناك مشكلة وصعوبة في تعلم الطفل للمفاهيم الرياضية ومن هنا جاءت البحث من أجل الكثف عن أثز استخدام إبــتر اتيجية المشروعات في تتمية بعض المفاهيم الرياضية لدى طفل الروضة. تحديا مشكلة البحث:

في ضوء ما نادت به المؤتمر ات و الدر اسات السابقة من ضرورة إكسـاب طفل الروضة المفاهيم الرياضية، بالإضافة إلى قلة الدراسات التي اهتمت بذلك؛ ومن أجل هذا تتحدد مشكلة البحث في السؤال الرئيسي التالي:

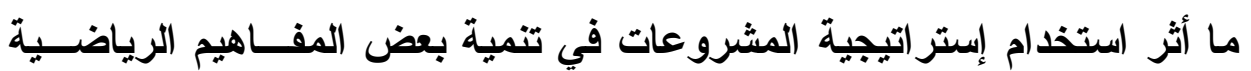

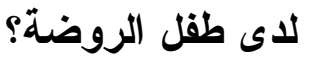
ويتفرع من هذا السؤ ال الرئيس الأسئلة الفرعية التالية:

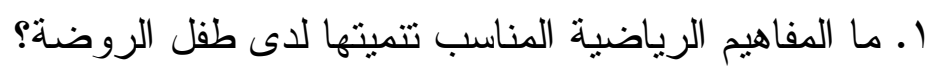

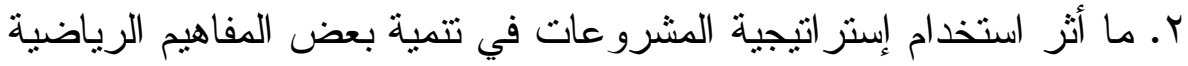

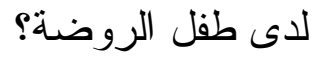

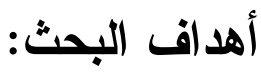

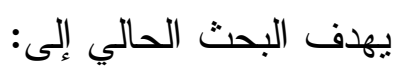
1- تحديد المفاهيم الرياضية المناسب تتميتها لدى طفل الروضة.

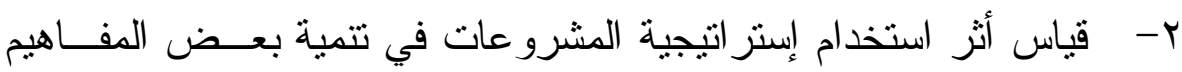
الرياضية لدى طفل الروضة. 
يحاول البحث الحالى اختبار صحة الفروض التالية:

1-توجد فروق ذو دلالة إحصائية بين متوسطي درجات أطفال المجمو عتين

(التجريبية و الضابطة) في التطبيق البعدي لاختبـار الدفــاهيم الرياضـــية

المصور لصالح المجموعة التجريبية.

ץ-توجد فروق ذو دلالة إحصائية بين متوسطي درجات أطفال المجموعـــة

التجريبية في التطبيقين (القبلي و البعدي) لاختبــار الدفــاهيم الرياضـــية المصور لصالح التطبيق البعدي.

ب-يحقق تدريس الإستر اتيجية المقترحة حجم تأثنر كبير باستخدام مربع إيتــا سكوير أعلى من القيمة (ع ا, •) في تتمية اختبار الدفاهيم الرياضية كـــل ومفاهيمه الرئيسة لدى أطفال مجموعة البحث. أهمية البحث: تتمثل أهمية البحث الحالي فيما يلي: أولاً: الأهمية النظرية:

1-توفير بيئة تربوية سليمة لأطفال الروضة من خلال المشروعات المنتوعة الماته

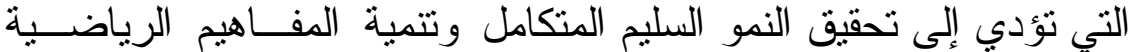
بشكل جذاب للطفل. r-تُعد النعلم بالمشرو عات بيئة مشوقة وممتعة لأطفال الروضة.

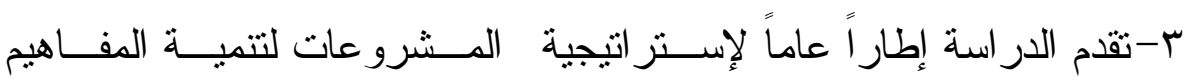
الرياضية لطفل الروضة. 
ع-تتبع أهمية الدر اسذة من كونها تؤكد على تتمية المفــاهيم الرياضــية فـي مرحلة عمرية حاسمة هي مرحلة رياض الأطفــال، وصــل شخــصيته و التعبير عما بداخلها في تلقائية وعفوية تتفق مع حاجاتهم وميولهم وتعديل سلوكاتهم.

ه- التأكيد على أهمية استخدام إستر اتيجية المشروعات في تحقبــق التتميــة المتكاملة لطفل الروضة في ضو ء فلسفة المناهج و أهدافه. 7- التعرف على أهمية الإستر اتيجية المقترحة خصيــصـًا لتتميــة المفــاهيم الرياضية لدى طفل الروضة. ثانياً الأهمية التطبيقية:

1- تقديم أسلوب تعليم يعتمد على المشروعات يختلف عن الأساليب المتبعـــة في رياض الأطفال بتتمية المفاهيم الرياضية. ץ- تخدم هذه الدر اسة المربين ومعلمات رياض الأطفال في نماذج من هـــه الأنشطة القائمة على المشرو عات. ب- تقديم مجموعة من الأنشطة القائمة على المشروعات لإكــــاب الأطفـــال المفاهيم الرياضية. ع- يمكن الاستفادة من هذا البحث في توجيه أنظار المسئولين عـن تخطــيط المناهج إلى وضع أنشطة قائمة على المشروعات تتمى المفاهيم الرياضية لاى طفل الروضة.

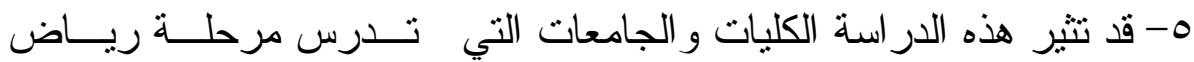
الأطفال بضرورة الاهتمام بالأنشطة القائمة على المشروعات، وما يتعلق بها وتدريسها كمساقات مستقلة أو ضمن بر امج وخطط. 
مصطلحات البحث:

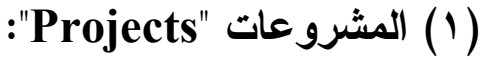

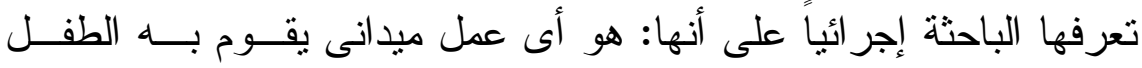

وينسم بالناحية العلمية؛ وتحت إثر اف معلمة الروضة؛ ويكون هادفاً ويخدم مادة

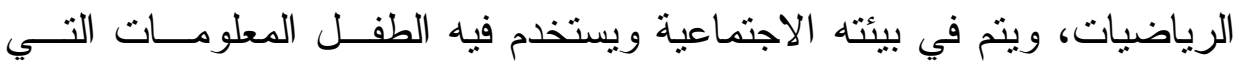
تعلمها؛ و هدفه تتمية بعض المفاهيم الرياضية لديه.

( آ) المفاهيم الرياضية "Math Concepts") تعرفها الباحثة إجر ائيًا على أنها: التجريد العقلى للصفات المـشتركة بــين

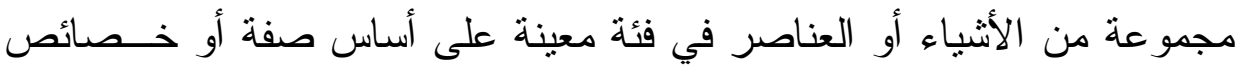

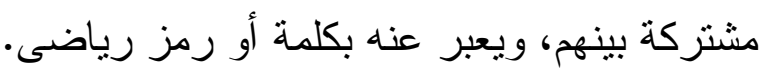
منهج البحث و التصميم التجريبي: سوف تستخدم الباحثة كلاً من:

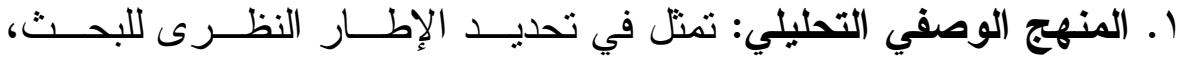
و إكساب أطفال الروضة الدفاهيم الرياضية وتحديد أهم الدفاهيم الرئيسـسة لمادة الرياضيات المناسب تتميتها لاى طفل الروضة (عينة البحث)، وبناء

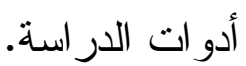
r. المنهج التجريبي: وذلك للتعرف على أثز استخدام المشروعات في تتمية الدفاهيم الرياضية لدى طفل الروضة. 


\section{حدود البحث:}

• عينة من أطفال الروضة (المستوى الثاني) بروضتى المنصورة الرســية للغات، وروضة مدارس ناصر الرسمية للغات.

• تم تطبيق المعالجة التجرييية خلال الفصل الدراسي التُــي مــن العسام

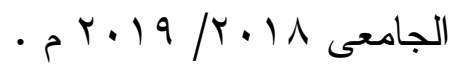

ق قياس ثلاث مفاهيم رئيسة للمفاهيم الرياضية (التصنيف، الجمع و الطـــرح،

$$
\text { مو اد وأدوات البحث: }
$$

قائمة ببعض الدفاهيم الرياضية المناسب تتميتها لدى طفل الروضة (إعداد

$$
\text { الباحثة). }
$$

• اختبار المفاهيم الرياضية المصور لطفل الروضة (إعداد الباحثة).

• المشرو عات اللازمة لتتمية بعض المفاهيم الرياضية (إعداد الباحثة).

الإطار النظرى للبحث:

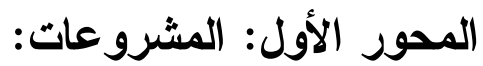

$$
\text { مفهوم المشروعات: - مفات }
$$

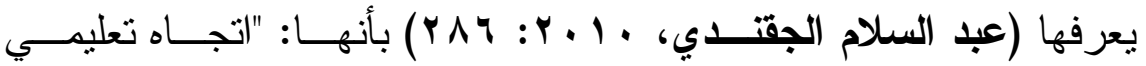

وفلسفة تعليمية تتجه بأسلوب التدريس نحو الناحية العملية ليتعلم الأطفــال عـنـ

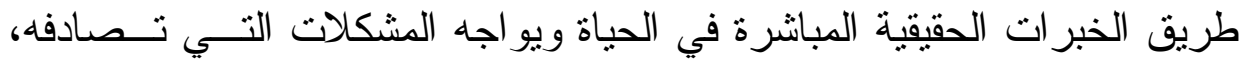
ويفكر في الحلول المناسبة لها". 


$$
\text { أولاً: المشروعات الجماعية: تتقم المشروعات بحسب عدد المشاركين فيها إلى قسمين: }
$$

هي تلك المشروعات التي يطلب فيها من جميع الأطفال فـي القاعــة أو المجموعة الواحدة القيام بعمل واحد، كأن يقوم جميع الأطفال بتمثيل مسرحية أو رواية معينة كمشاركة منهم في احتفالات المدرسة أو كأحد الو اجبات الدر اســية المطلوبة منهم.

$$
\text { وثاتياً: المشروعات الفردية: }
$$

• النوع الأول: يتطلب من جميع الأطفال تتفيذ المشروع نفسه كلا على حده

مثل أن يرسم عن انتصـار ات أكتوبر، أو أن يلخص قصه بـشنكل صــور

$$
\text { تحددها المعلمة. }
$$

• النوع الثاني: وهو عندما يقوم كل طفل في المجموعــة باختيــار وتتفيــذ مشروع معين من مجمو عة مشرو عات مختلفة يتم تحديدها من قبل المعلمة

$$
\text { أو الأطفال أو الإثتان معاً. }
$$

خطوات عمل المشروع:

تمر عملية انجاز المشروع بأربع خطو ات رئيسية كما أثنار لهــا ويجنــر

$$
\text { و آخرون (Wegner C., et al., 2013, 138) هي: }
$$




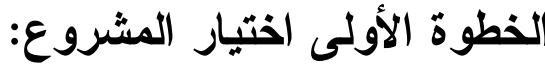

الاختيار الجيد يساعد في إنجاز ونجاح المشروع، بينما الاختيار السيئ أو

الفشل في الاختيار المناسب يعرض المشروع للفـشنل الحتـــي ويجــل مــن

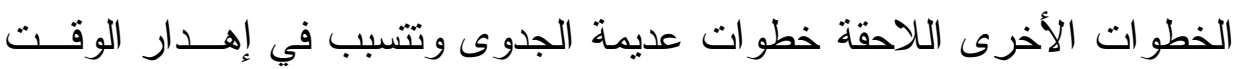
وعلى المعلمة لتحقيق هذه الخطوة مر اعاة ما يلي:

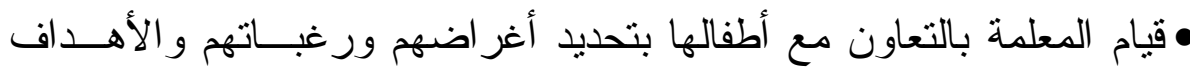

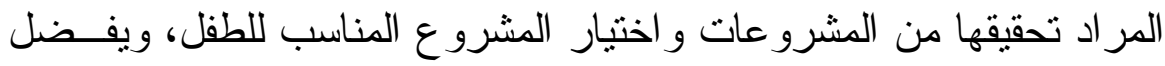

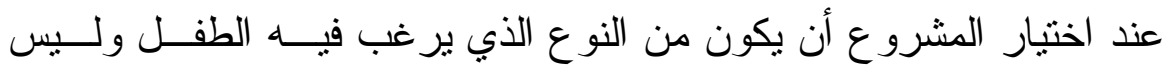
المعلمة، لأن ذللك يدفع الطفل و يشجعه على القيام بالعمل الجـاد و انجـــاز

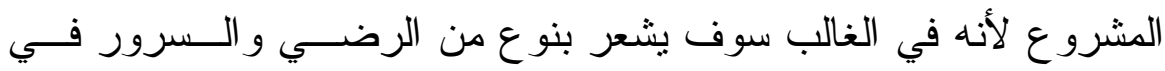

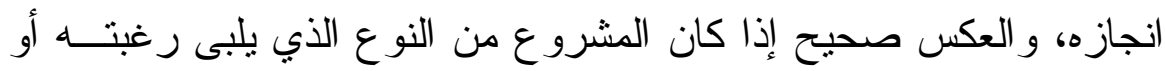

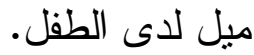

• كما ير اعى في اختبار المشروع أن يكون من النوع الذي يمكن انجـازه؛ إذ

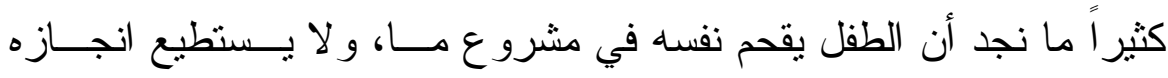

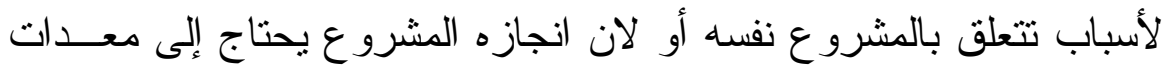

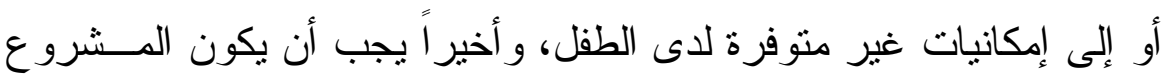

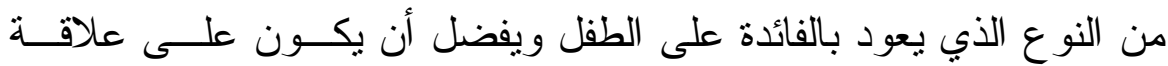

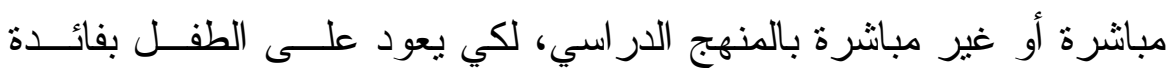
تربوية. 


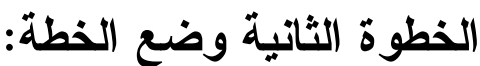

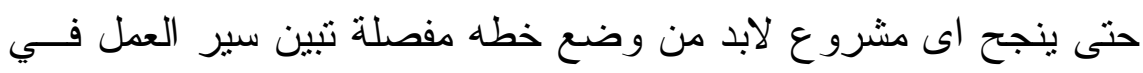

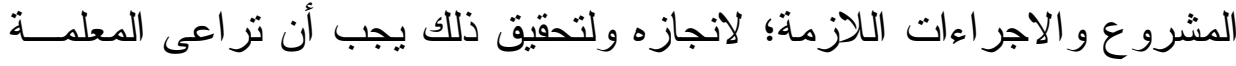

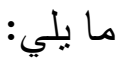

•يضع الطفل بالتعاون مع المعلمة خطه مفصلة و اضــــة لتنفيــذ المـشروع

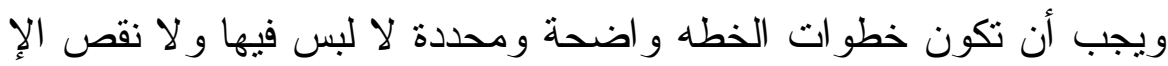

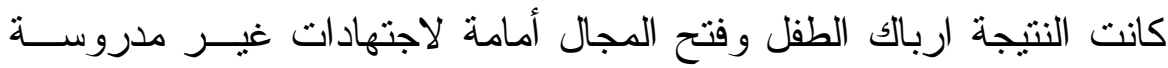
و التي منشأها عرقلة العمل وضياع وقت الطفل وجهده.

•و لأبد من التأكيد هنا على أهمية مشاركة الأطفال في وضع الخطه و إبــــاء أر ائهم ووجهات نظر هم.

• دور المعلمة هنا ذا طابع استتشارى، يسمع أداء الأطفال ووجهات نظـــرهم

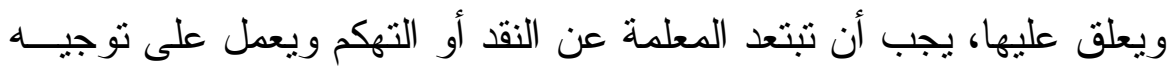

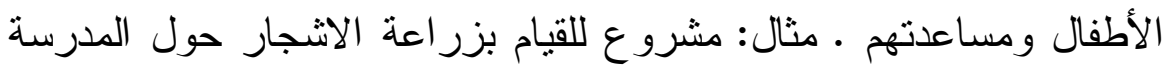
وقد تم وضع خطه تفصيلية لهذا المشروع تضمنت: 1. إ. توزيع العمل على الطلبة. r. وتحديد أماكن زر اعة هذه الأشجار وكيفيه الحصول عليهــا و المعـدات اللازمة مثل أدو ات حفر التزبه و غير هاعها.

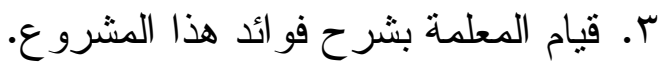

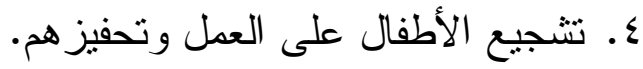




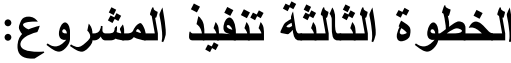

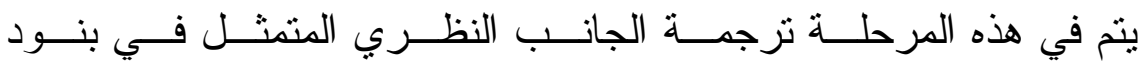
خطه المشروع إلى و اقع عملي محسوس؛ حيث يقوم الطفل في هذه المرحلة بما يلي:

تتفيذ بنود خطه العمل. تتمية روح الجماعة و التعاون بين الأطفال.

التحقق من قيام كل منهم بالعمل المطلوب منه وعدم الإتكال على غيــره

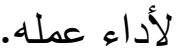

التأكيد على ضرورة التز ام الأطفال بنود خطه المشروع وعدم الخــروج أنسا عنها الإ إذا طر أت ظروف تستدعى إعاده النظر في بنود الخطة و عندها تقوم المعلمة بمناقثة الموضوع مع الطلبه والإتفاق معهم على التعـديلات

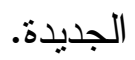

الخطوة الر ابعة تقويم المشروع:

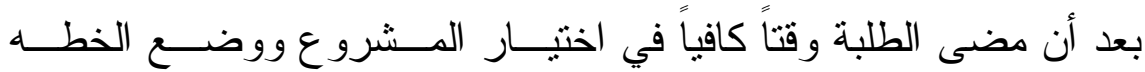
التقصيلية له وتتفيذه، تأتى الخطوة الر ابعة و الاخيرة من خطوات المشروع إعداد

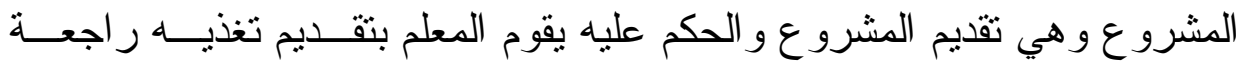

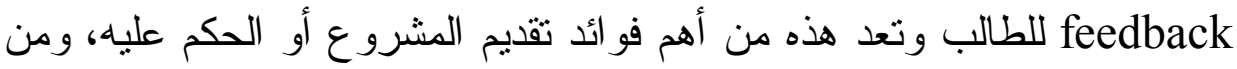

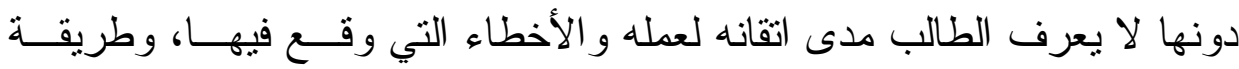

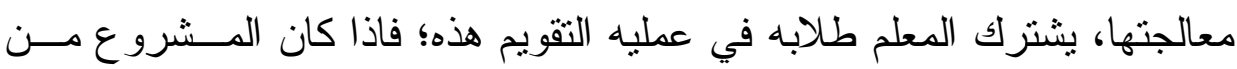

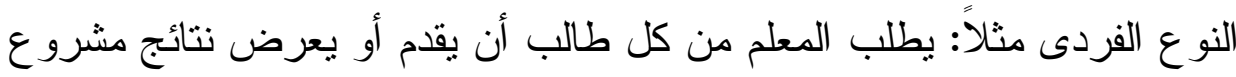


هو ما قام به على بقيه الطلاب ويقوم الطلاب بمناقثة المشروع وتقديم تعليقاتهم

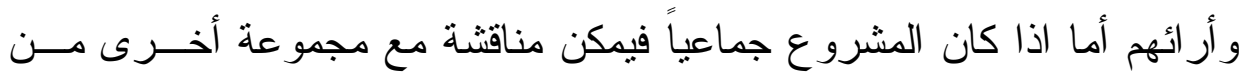
الطلاب وان تعذر ذلك يقوم المعلم بمناقشته معهم. خصائص إستراتيجية المشروعات:

(Bertrand., تركز إستر اتيجية المشروعات كما أثنار لها برتز اند جي J, 2007, 12)

• بركز على المشكلات التي تفتقر إلى حلول محددة مسبقاً وخاصـــة تلـــك المتعلقة بمادة الحاسب الآلي. • يركز على الأسئلة المفتوحة والمهام التي تثثر التحدي. يقوم الأطفال بإتخاذ القرارات و المساهمة في الوصول للحلول المكنة. يحسن دافعية الأطفال إلى معرفة المحتوى و المهار ات الأساسية. • بوفر جواً من تحمل المسؤلية لدى الأطفال. • بتطلب التفكير الناقد و التمكن من حل المشكلات و التعاون ومختلف أثنكال

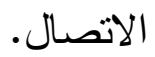
• يشتمل على التخذية الر اجعة و التقويم بشكل مستمر . • يضيف نوع من المتعة أثثاء عملية التعليم عن طريق الحاسب الآلي. معمل على الخروج بمنتج نهائي وتقويمه. 
لإستر اتيجية المشروعات عدة مز ايا وهي كما أنثار اليها كل من (توفيـق

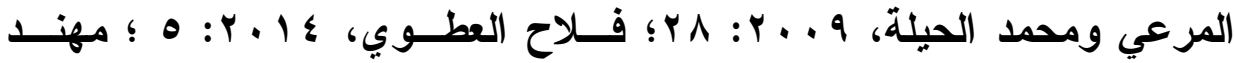

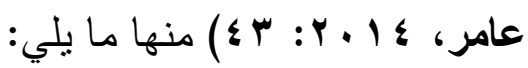

• تشجع المشروعات الطلابية عملية البحث و التأمسلـل و الاستفـسار النـشط و الارتقاء بالتفكير ؛ مما ينعكس على نشاط الطلاب العلمي. تعزيز قدر اتهم في التعلم الذاتي في حسلـ المـشكلات؛ حينــــا يز اولــون

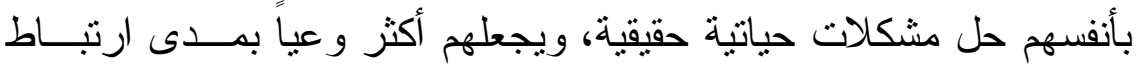
الحقائق العلمية بالمهار ات و الحياة.

يزود الأطفال بمهار ات لا غنى عنها في التعليم العالى، فالأطفال يتعلمون

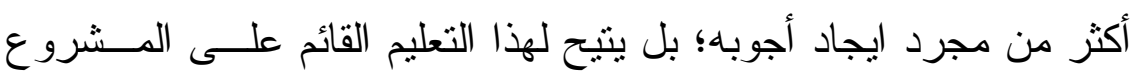
نوسيع عقولهم و التفكير فيها ور اء ما يفعلون.

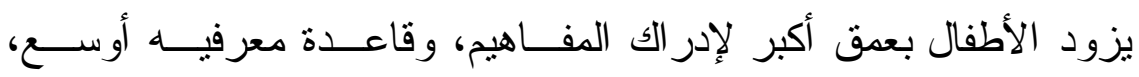

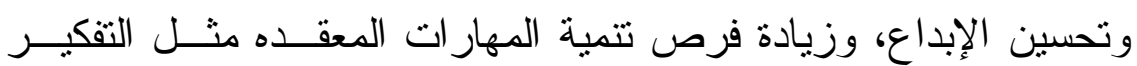
بمستوى أعلى وحل المشكلات و التعاون و الاتصال.

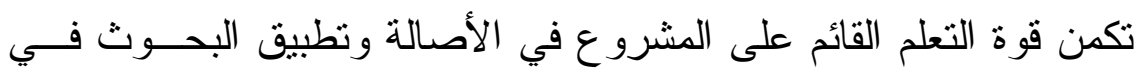

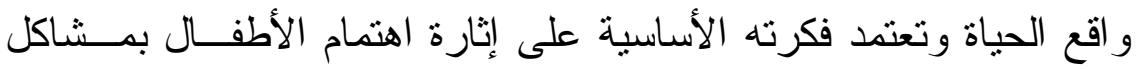

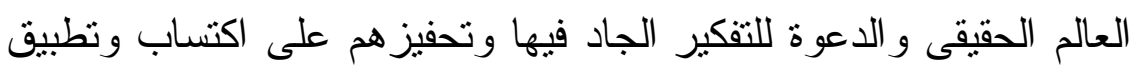
المعرفة الجديدة في سياق حل المشكلة.

المجلد السادس


يتيح فرصة التنافس الثريف بين المجموعات المتكافئة التي تتضمن كافة

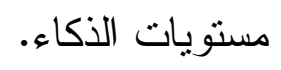

التصميم الجيد للمشاريع يشجع البحث النشط وينمــى مهــار ات التفكيــر

العليا؛ فالعقل يبحث ليكتشف قيمه ومعنى أنشطة التعلم، ومن ثم تتحسـن

$$
\text { قدر ات الاطفال باكتساب فهم جديد. }
$$

تساعدهم محاو لات حل المشكلات على فهم لمسـاذا؟ ومتـى ؟ وكيـــ؟

$$
\text { ارتبطت تلك الحقائق. }
$$

تعقيب: وتضيف الباحثة بعض النقاط التالية في مز ايا إستر اتيجية المــشروعات

$$
\text { وهي: }
$$

تعميق التعلم لدى الأطفال وقدرته على منحهم الفرصة لمو اجهة مشكلات

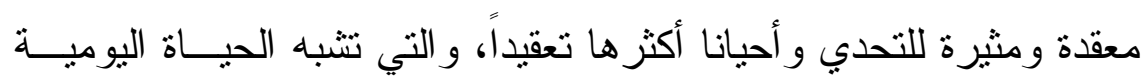

$$
\text { بشكل كبير - n مبن }
$$

يساهم في إثر الك الأطفال في التخطيط و التنظـــيم و التتفيــــ و الإثـــر اف

$$
\text { و التقويم للعملية التعليمية و التزبوية. }
$$

يساعد في تحفيز هم وتقليل نسبة الغياب وتعزيز مهار ات التعلم التعــاوني وتحسين الأداء الأكاديمي، كما يزيد من نسبة حضور الأطفال و اعتمادهم

$$
\text { على الذات وتحسين اتجاهاتهم نحو التعلم. }
$$

يكسب المعلمين مزيدًا من الخبرة في مجال التعلـيم و التــدريب وزيـــادة

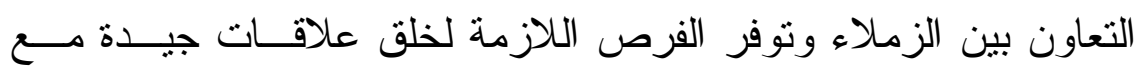
الطلاب.

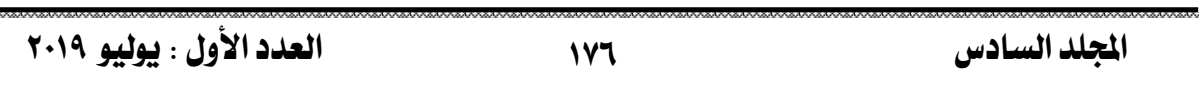


المشاريع تضع الطلاب في مناخ نشط لحل مشكلة وصنع القرار و التحقق منه وتوثيقه.

كما أن الأنشطة في المشرو ع تستدعى بحث وبناء لمعارف جديدة لــدى الطالب.

تتمى طريقة المشروع عند الأطفال روح العمل الجماعى و التعاون كـــــا هو الحال في المشروعات الجماعية.

تتمي عند الأطفال روح التتافس الحر الموجه في المشروعات الفردية. من طر ائق التدريس التي تتجع على تفريد التعليم.

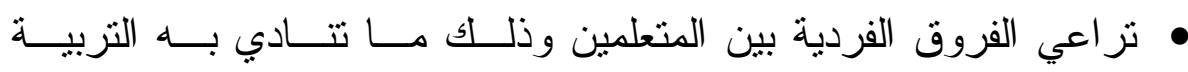
الحديثة.

تجعل المتعلم محور العطلية التزبوية بدلاًا من المعلم؛ فهو الــذي يختــار المشرو ع وينفذه تحت إنثر اف المعلم.

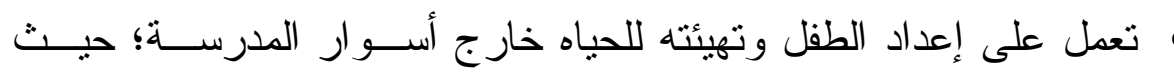

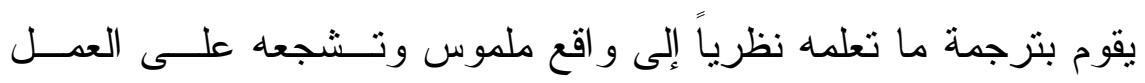

$$
\text { و الإنتاج. }
$$

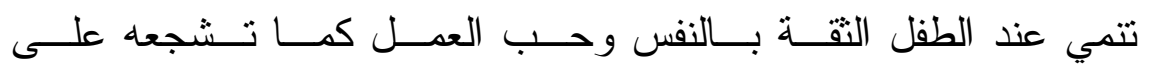
الإبداع و الابتكار وتحمل المسؤلية وكل ما من شأنه مساعدته في حياتــه العملية. 


\section{عيوب إستر اتيجية المشروعات:}

على الرغم من تعدد مميز ات طريقة المشرو عات كإحــدى إبـــتر اتيجيات

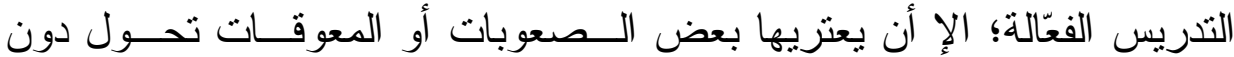
تطبيقها على أكمل وجه؛ منها النقاط التالية:

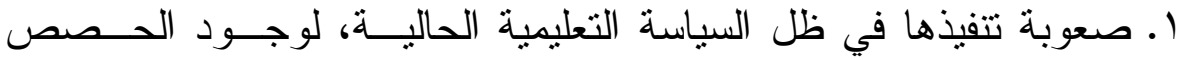
الدر اسية و المناهج المنفصلة وكثره المو اد المقررة. r. تحتاج المشروعات إلى إمكانيات ضخمة؛ من حيث الموارد المالية وتلبيه

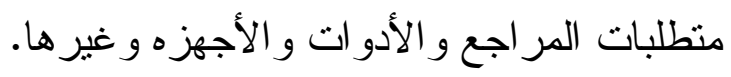

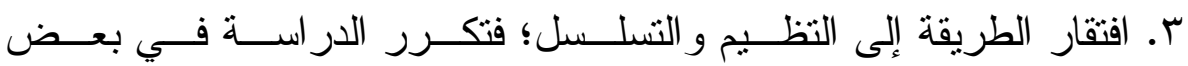

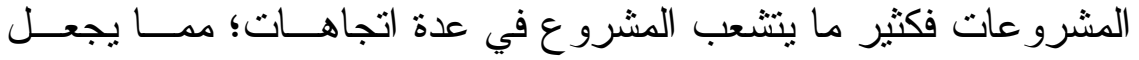
الخبرات الممكن الحصول عليها سطحية غير منتظمة. ع. المبالغة في إعطاء الحرية للتناميذ، وتركيز العملية حول ميول الأطفــال، وترك القيم الاجتماعية و الاتجاهات الثقافية للصدفه وحدها. المحور الثاني: المفاهيم الرياضية: مفهوم المفاهيم الرياضية:

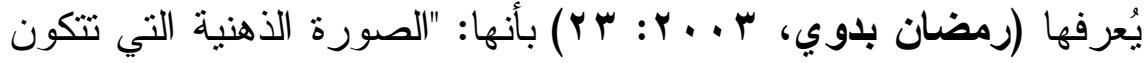

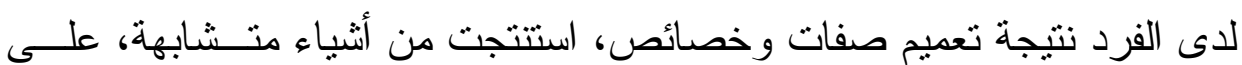
أثنياء يتم التعرض إليها فيما بعد".

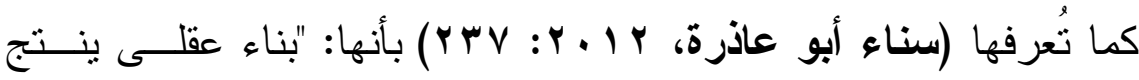

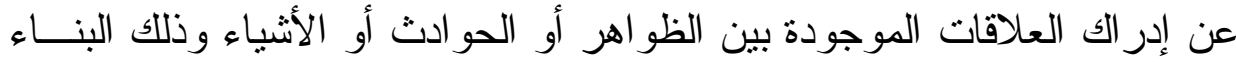


غالباً ما يقوم على أساس تتظيم تلك الظو اهر أو الأشياء في أصناف أقــل منهـــا

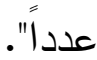

\section{خصائص المفاهيم الرياضية:}

تتميز المفاهيم بمجموعة من الخصائص وفقاً لما أثنارت إليـــه الأدبيــات

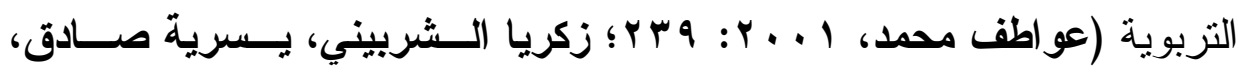

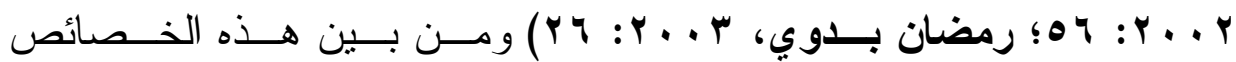
ما يلي:

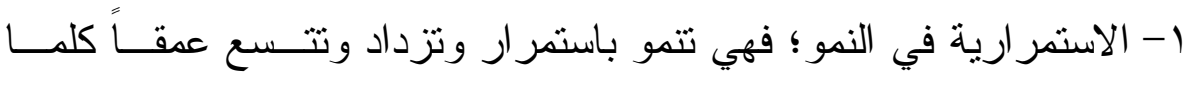

$$
\text { ز ادت الخبرات التي يتعرض لها الفرد طو ال حياته . }
$$

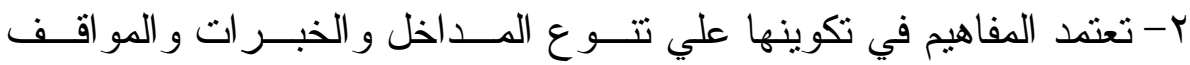
التعليمية التي بتعرض لها المتعلم. ب- تعتمد المفاهيم على مستوى النضـج.

ع- تتدرج المفاهيم من البسيط إلى المعقد، ومن المحسوس إلى المجرد. 0- العديد من المفاهيم التي يشيع استخدامها نمثل رموز، وتتمنل في الكلمات و الأرقام و العلامات و البنود وبنود أخرى عديدة تصنف أثنياء أو أحــداثًا معينة.

צ- تتسم المفاهيم بصفة العمومية؛ حيث يتم التوصل إليها عن طريق تعدــيم العديد من الخبر ات، و ادر الك العلاقات بينها.

V- تعتمد المفاهيم في تكوينها على الخبرة السابقة للمتعلم، و الخلفيــة التقافيــة و الفرص التعليمية يمكن أن تمنل متغير ات في نكوين المفاهيم. 1- يرتبط بتكوين المفاهيم الجو انب انفعالية و الجو انب الادر اكية للفرد. 
المفاهيم الرياضية الخاصة بطقل الروضة:

سوف تقتصر الباحثة في هذا البحث على المفاهيم الرياضية التالية:

$$
\begin{aligned}
& \text { • التصنيف. } \\
& \text { • الجمع و الطرح. } \\
& \text { • العدد. } \\
& \text { وفيما يلي تقصيل لذلك: } \\
& \text { 1- مفهوم التصنيف: }
\end{aligned}
$$

يُعرف التصنيف على أنه: القدرة على ضم الأثياء معاً فـي مجموعـات

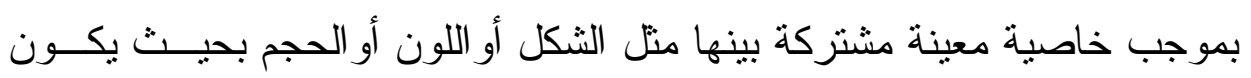

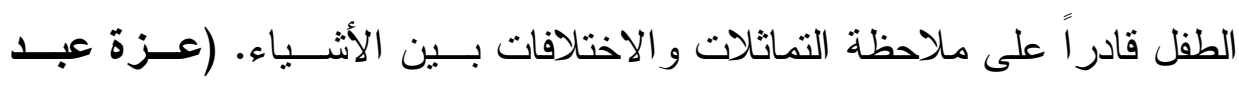

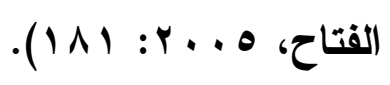

ويهدف تعلم التصنيف إلى تمكين الطفل من تحديد الخاصية المميزة لتلـــك

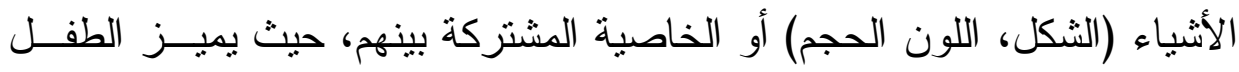

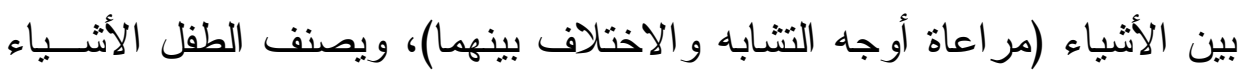

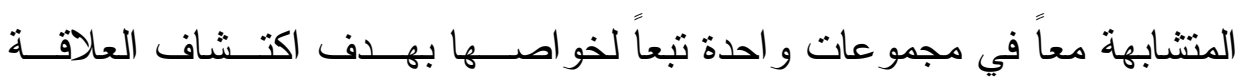

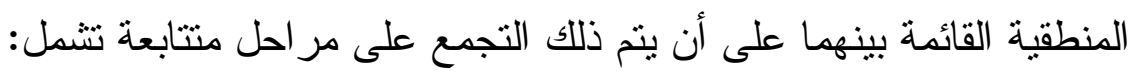
تصنيف الأنثياء وفق خاصية واحدة (الثكل ،اللون ،الحجم) .

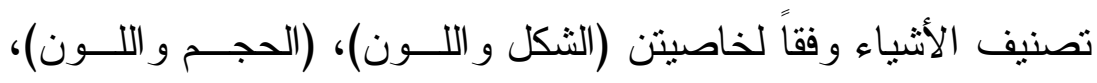

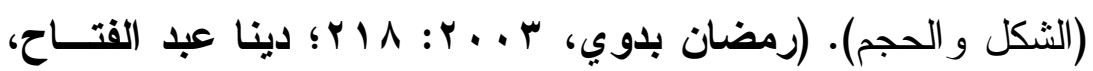
.$(10: 4 \cdot 1)$ 


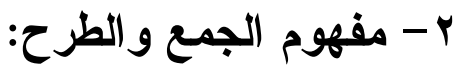

تعرفا على أنهما: "عمليتى ضم أو فصل عناصر مجمــوعنين مـستقليتن

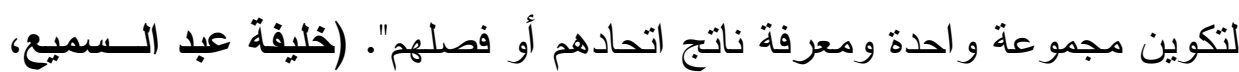
.( ) $9 \vee: Y . .1$

و الأطفال يتعلموا العلاقات بين الأعداد و التمييز بين المجموعتين بعبار ات

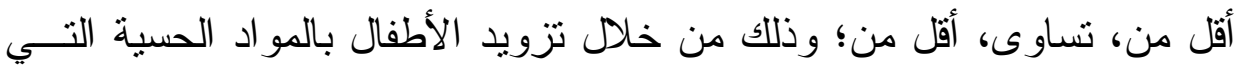

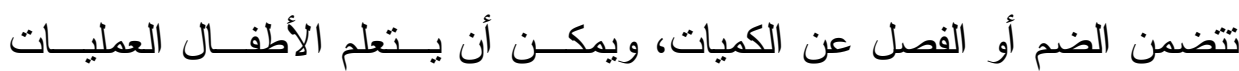

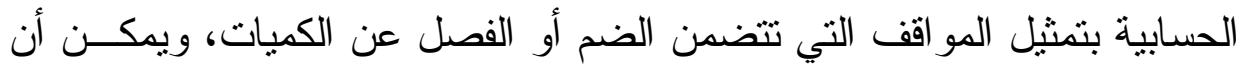

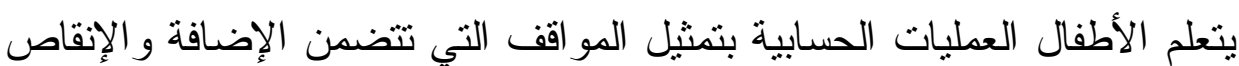

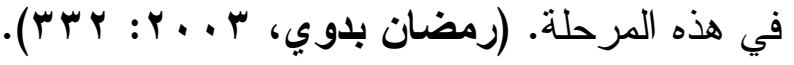

$$
\begin{aligned}
& \text { r- r - مفهوم العدد: }
\end{aligned}
$$

يعتبر مفهوم العدد من المفاهيم المركبة التي تتضمن مهارتين منفصلتين:

الأولى: تتعلق بقدرة الطفل على الإبداع اللفظى لـجموعة الكلمات التـي

$$
\text { تستخدم في العد بالترنيب (و احد، انثين، ثلاثة، أربعة، ل...). }
$$

الثانية: تتعلق بقدرة الطفل على ربط كل كلمة في مجموعة كلمات العـــ

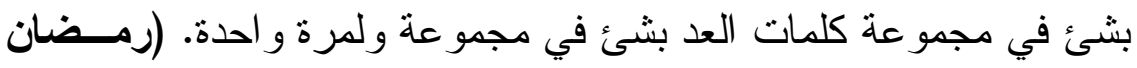

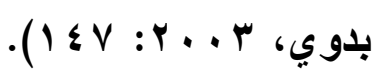

$$
\text { أهمية تعلم المفاهيم الرياضية: }
$$

تعتبر الدفاهيم ذات أهمية كبيرة؛ لأنها تزود المتعلم بوسيلة بستطيع بهــا

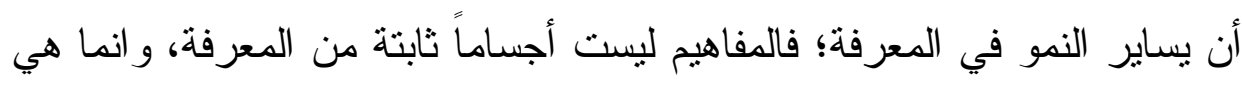

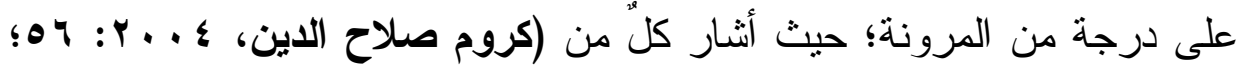

اليجل البادس




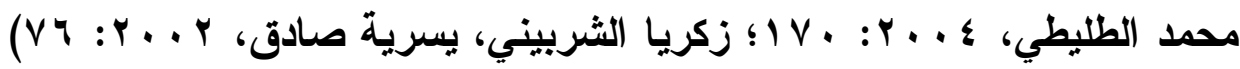

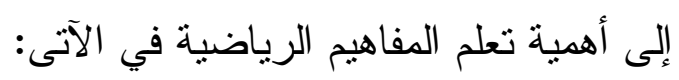

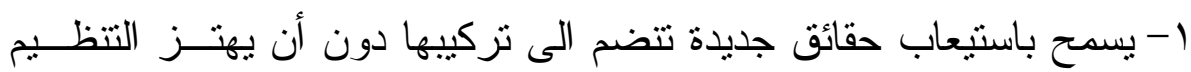

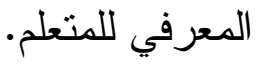

r- يجعل المتعلم فادراً باستمر ار على ملاحظة الزيادة في المعرفة.

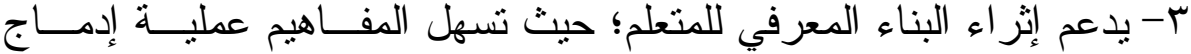

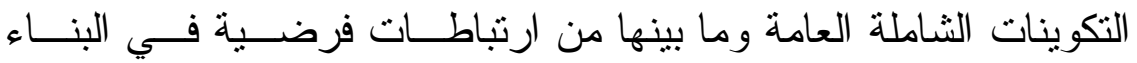

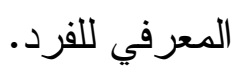

ع- يساعد المتعلم على الاستتناج و التطبيق.

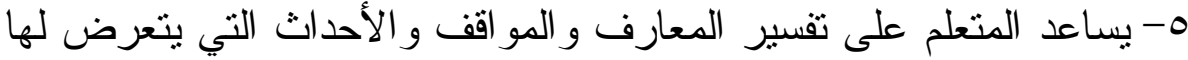

سو اء كانت جديدة أو غير مألوفة بالنسبة له.

צ- يساعد المتعلم على انتقال أثز التعلم في المو اقف المختلفة.

V- يساعد المتعلم على التتبؤ و التخطيط لحل المشكلات فعندما يكون المــتعلم

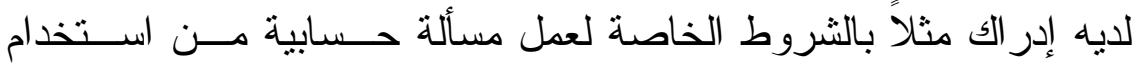

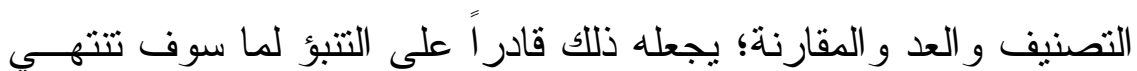

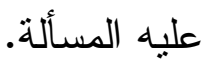

دور المعلمة في تنمية المفاهيم الرياضية لطفل الروضة باستخدام إســتراتيجية

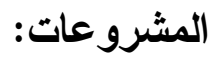

تلعب معلمات الروضة دورًا هامًا في تتمية الدفــاهيم الرياضــــة لطفــل

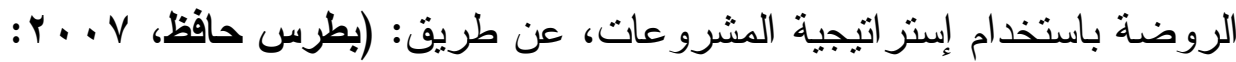

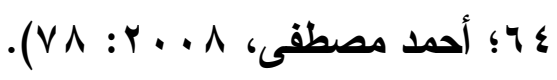


• توفير فرصًا كبيرة للأطفال للمشاركة في تتفيذ المـشروعات و الانــدماج

فيها.

• توفير الييئة المناسبة لتساعده في التفاعل مع الآخرين.

•تمية مهارة استيعاب التعليمات وتتفيذ الأوامر الدوجهة للطفل.

الإكثار من المثير ات وتتويع التدعيم المعنوى و المادى.

تكوين علاقة حميمة مع الطفل.

• زيادة مستوى الطموح و التتافس و التعاون.

• استثارة قدرة الطفل على الملاحطة و إتاحة الفرصة له لاستخدام حواســه

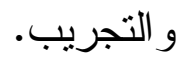

اكساب الطفل بعض المفاهيم الرياضية بطريقة مبسطة من خلال عـرض

نماذج للأنشطة النزبوية.

ه تمية قرة الطفل ادر الك العلاقات بين الأشثياء المختلفة من خلال عـرض

نماذج للأنشطة النربوية.

ت تمية قدرة الطفل على ادر الك العلاقات بين الأشياء المختلفة مسن خــدل

ادر الك مفاهيم الثكل و الحجم و المساحة.

تسهيل تتمية الدفاهيم الأوليــة للرياضـيات فــي الأعـــاد، و التــصنيف،

و الأوليات المنطقية، و العلميات و الدو ال.

التعرف على الأعداد و المعاملات الحسابية ذات العلاقة بالحياة اليومية أي

تهيئة عقل الطفل لمبادئ الرياضيات الأولية ومفاهيمها البسيطة.

المجلد السادس


استخدام أساليب و أنشطة حسية قائمة على المشرو عات.

وضع خطط لقضاء وقت في إنجاز المشرو عات.

الإطار التجريبي للبحث:

للإجابة عن أسئلة البحث و التحقق من صحة الفروض تم إتباع الإجر اءات

أولاً: إعداد قائمة بالمفاهيم الرياضية المناسب تنميتها لاى طقل الروضة: للإجابة على السؤ ال الأول من أسئلة البحث وهو :

ما المفاهيم الرياضية المناسب تنميتها لاى طقل الروضة؟ تم إعداد القائمة وفقا للإجر اءات التالية: ( ) تحديد الهدف من إعداد القائمة. r) إعداد الصورة الأولية للقائمة. r) تطبيق استبانة المفاهيم الرياضية على مجمو عة من معلمــات ومــشرفات

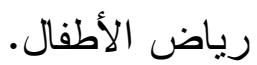
ويمكن توضيح الإجر اءات بالتقصيل فيما يلي: 1 - تحديد الهذف من إعداد القائمة:

تهدف القائمة إلى تحديد المفاهيم الرياضية المناسب تتميتهـــا لــدى طفـلـل

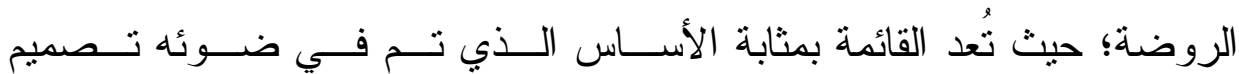
المشرو عات لتتمية المفاهيم الرياضية لدى طفل الروضة. 
تم إعداد الصورة الأولية للقائمة من خلا:

الإطلاع على الأدبيات و البحوث و الدر اسات السابقة التي تتاولت المفــاهيم

$$
\text { الرياضية. }
$$

$$
\text { • مصائص طفل الروضة. }
$$

ومن خلال ما سبق استطاعت الباحثة إعــداد الــصورة الأوليــة لقائمــة بالمفاهيم الرياضية المناسب تتميتها لدى طفل الروضة، وقد اثــتملت الــصورة الأولية للقائمة على خمسة مفاهيم يندر ج تحت كل مفهوم التعريف الإجر ائي لــهـ وهي:

$$
\text { • • • • • مفهوم التصنيف. مفهوم التباين. }
$$

تم تضمين القائمة في صورتها الأولية في صورة استبانة*؛ و التي هــدفت إلى تحديد مدى أهمية المفاهيم الرياضية الرئيسة لطفل الروضـــة مــن خــله مقياس متذرج (هام بدرجة كبيرة، هام بدرجة متوسطة، هام بدرجــة ضــعيفة، غير هام). 
وقد نم عرضها في صورتها الأولية على مجموعة من المحكمـين مسن

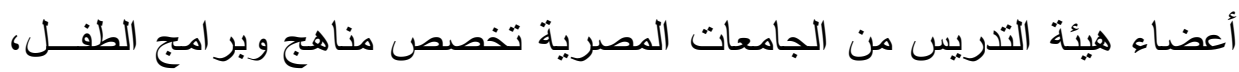

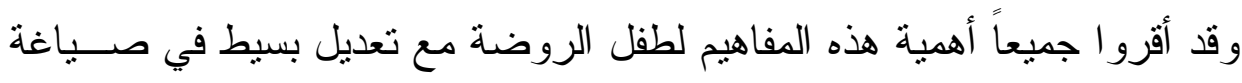
بعض التعريفات الإجر ائية لتلك المفاهيم. ب- تطبيق استبانة المفاهيم الرياضية:

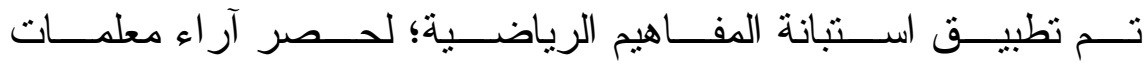

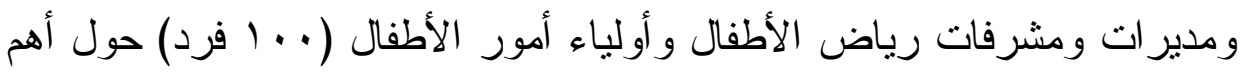

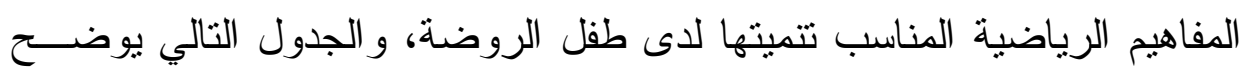

(") ملحق (1): استباتة المفاهيم الرياضية المناسب تنميتها للى طفل الروضة.

جدول (1)

"آراء العينة حول المفاهيم الرياضية المناسب تنميتها

\begin{tabular}{|c|c|c|c|c|c|c|c|c|c|}
\hline \multicolumn{10}{|c|}{ لاى طفل الروضة (ن= = 1)". } \\
\hline \multicolumn{8}{|c|}{ الاستجابات } & \multirow{3}{*}{ الرئيسة } & \multirow{3}{*}{ b } \\
\hline هام & غير & | ضعيفة | & بدرجة & متوسطة & هام بلرجة & كبيرة & بدرجة & & \\
\hline$\%$ & s & $\%$ & s & $\%$ & s & $\%$ & ك & & \\
\hline v & v & . & . & $r$ & $r$ & 9. & 9. & التصنيف & 1 \\
\hline 7. & 7. & $r$ & $r$ & $\varepsilon$ & $\varepsilon$ & ז & r & التباين & $r$ \\
\hline ir & $\pi$ & $r$ & $r$ & 0 & o & A. & ^. & الجمع و الطرح & $r$ \\
\hline v. & v. & - & 。 & v & v & in & 11 & النسبة و التتاسب & $\varepsilon$ \\
\hline 1. & 1. & 11 & 11 & $\varepsilon$ & $\varepsilon$ & vo & vo & 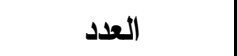 & . \\
\hline
\end{tabular}


من البيانات الو اردة في الجدول السابق و الخاص باستجابات أفر اد العينــة،

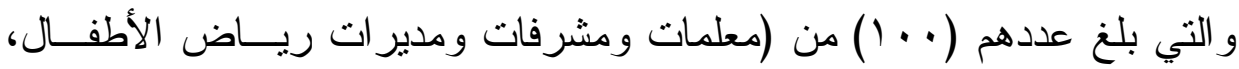

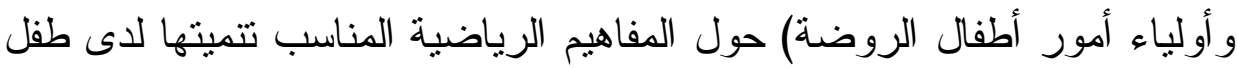

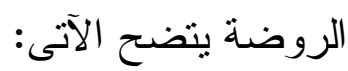

• احتل مفهوم "التصنيف" المرتبة الأولى بنسبة تكر ارية بلغـــ (بو\%\%) مـن حيث درجة الأهمية "بدرجة كبيرة".

• احتل مفهوم "الجمع والطرح" المرنبة الثنانية بنسبة تكر ارية بلغـــ (10\%)

$$
\text { من حيث درجة الأهمية "بدرجة كبيرة". }
$$

• احتل مفهوم "العدد" المرنبة الثالثة بنسبة تكرارية بلغت (\%9\%) من حيـث

$$
\text { درجة الأهمية "بدرجة كبيرة". }
$$

• احتل مفهوم "الثباين" المرنبة الر ابعة بنسبة تكر ارية بلغت (rr\%) من حيث

$$
\text { درجة الأهية "بدرجة كبيرة". }
$$

• احتل مفهوم "النسبة و التناسب" المرتبة الأخيرة بنسبة تكر ارية بلغت (0\%\%)

$$
\text { من حيث درجة الأهمية. }
$$

يتضح مما سبق إجماع أفراد العينة حول أهمية المفاهيم الرياضية الآتـــة بالنسبسة

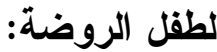

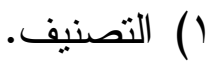

$$
\begin{aligned}
& \text { r) الجمع و الطر ح. } \\
& \text { r) العدد. }
\end{aligned}
$$

r.19 المجلد السادس


و هذه المفاهيم الرياضية الثلاثة هي التي تم تتميتها من خلال إبــتر اتيجية

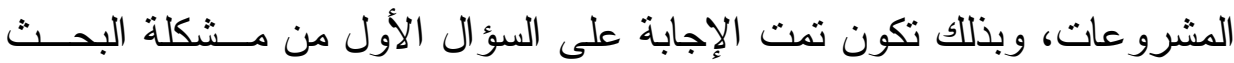

ما المفاهيم الرياضية المناسب تنميتها لدى طقل الروضة؟ ثالثاً إعداد اختبار المفاهيم الرياضية المصور: للإجابة عن السؤال الثالث من أسئلة البحث، الذي نص على:

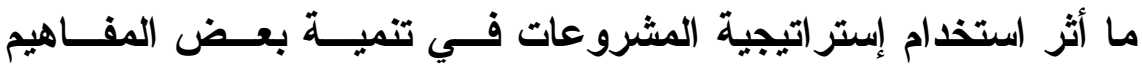
الرياضية لاى طقل الروضة؟ تم بناء اختبار الدفاهيم الرياضية المصور لدى طفــل الروضــة، ووفقــاً

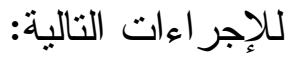
1 - ت تحديد الهدف من الاختبار: يهدف اختبـار الدفــاهيم الرياضــية المـصور إلـى قيــاس مـستوى الأطفال عينة البحث في بعض الدفاهيم الرياضية بعد تدريسها لها بإنــتر اتيجية

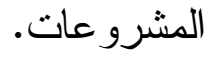

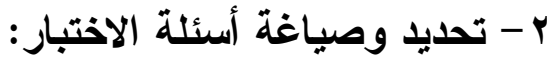
تم تحديد وصياغة أسئلة اختبار المفاهيم الرياضية المصور مــن خـلدل الإطلاع على بعض الأدبيات و البحوث و الدر اسات السابقة التي تتاولت الدفــاهيم

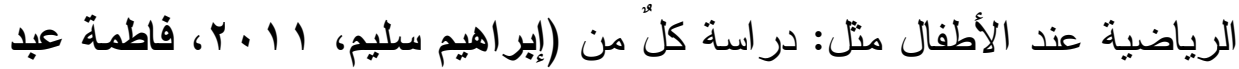

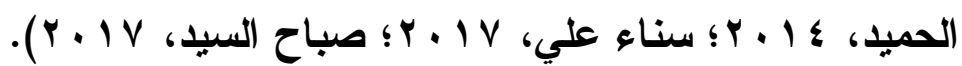

المجلد السادس




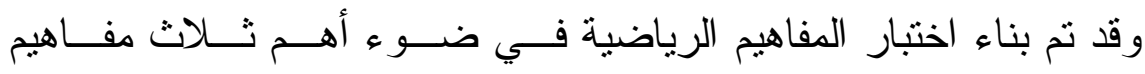

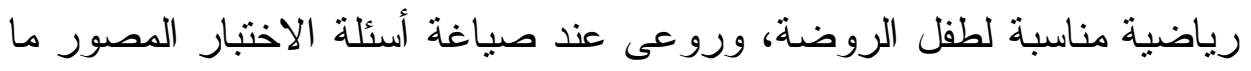

أ) أن أن تكون الصورة و اضحة.

ب) أن تكون اللغة المستخدمة مناسبة لطفل الروضة.

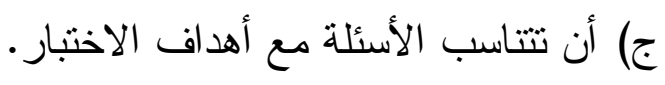

وقد استخدمت الباحثة أسئلة الاختيار من متعدد لكونـــهـ يتميـز بالــسهولة

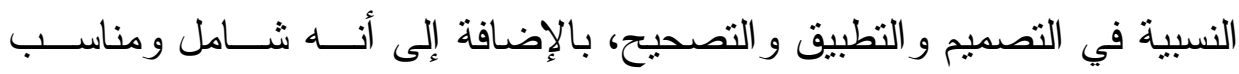

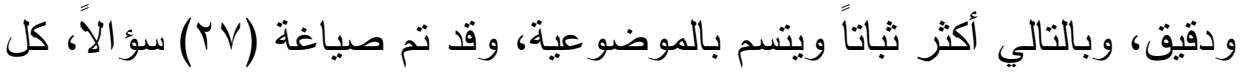

$$
\text { سؤ ال أسفله ثلاث صور ؛ كما في الجدول النالي: }
$$

\begin{tabular}{|c|c|c|c|}
\hline الوزن النسبي لكل مفهوم & عدد الأسئلة لكل مفهوم & المفاهيم الرئيسة لاختبار & p \\
\hline אז,זr & 9 & التصنيف & 1 \\
\hline 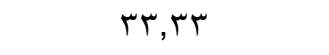 & 9 & الجمع و الطرح & r \\
\hline Tr, & 9 & العدد & $r$ \\
\hline$\% 1 \ldots$ & rV سؤالاً & المجموع الكلي & \\
\hline
\end{tabular}

جدول (ץ): عدد الأسئلة في اختبار المفاهيم الرياضية.

ب - تحديد طريقة تسجيل الارجات:

تم تصحيح أسئلة اختبار المفاهيم الرياضية المصور ، بحيث تُعطى الطفلـــة

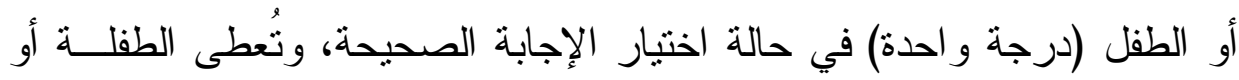

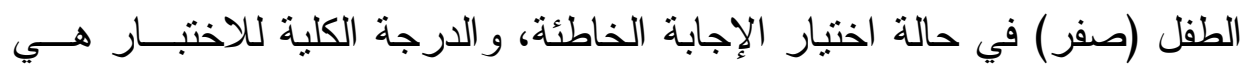

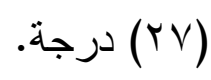




\section{צ - التحقق من صدق المقياس (صدق المحكمين):}

قامت الباحثة بعرض اختبار المفاهيم الرياضية الدصور بصورته الأولية على مجموعة من السادة المحكمين و الخبراء المتخصصين من أعـضـاء هيئـــة

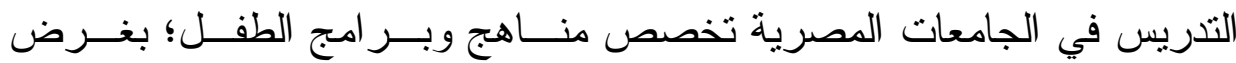

$$
\text { التعرف على آر ائهم من حيث: }
$$$$
\text { (Y) مدى وضوح أسئلة الاختبار . }
$$

r) مدى انتماء وقياس الأسئلة الفرعية باختبار الدفاهيم الرياضــية الــصور

$$
\text { لكل مفهوم رئيسي متضمنة بالاختبار . لكأل }
$$

r) سلامة الصياغة اللغوية لأسئلة الاختبار .

وقد أجمع أغلب السادة المحكمين على مناسبة الاختبار لطفل الروضة لإسنة.

$$
\text { ه - التجربة الاستطلاعية للاختبار: }
$$

تم تطبيق اختبار المفاهيم الرياضية المصور على المجموعة الاستطلاعية

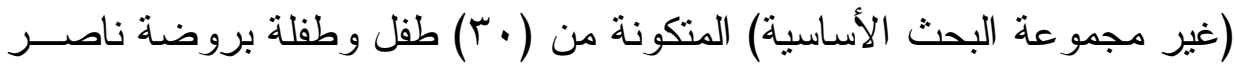

$$
\begin{aligned}
& \text { الرسمية للغات؛ وذلك بهذف: } \\
& \text { (Y) حساب صدق الاختبار . }
\end{aligned}
$$

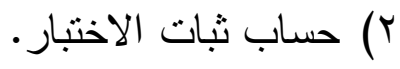

$$
\begin{aligned}
& \text { r) حساب زمن الإجابة عن الاختبار . } \\
& \text { وفيما يلي تمثل ذلك: } \\
& 1 \text { - حساب الصدق "التجانس الداخلي": }
\end{aligned}
$$

تم حساب الصدق لاختبار المفاهيم الرياضية المصور ، بحسساب معامـلـ

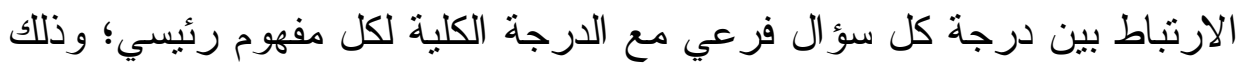

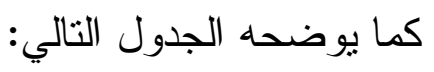


جدول (r)

معاملات الارتباط بين درجة كل سؤال فرعي من أسئلة الاختبار مع الارجة الكلية لكل مفهوم رئيسي.

\begin{tabular}{|c|c|c|c|c|c|c|}
\hline • & \{ & $r$ & r & 1 & المفردة & \\
\hline \multirow[t]{3}{*}{$\cdot, \varepsilon \leqslant r$} & $\because \cdot, V T r$ & $\because \cdot 01 r$ & $\because, \varepsilon \cdot r$ & $"$ ", nor & معامل الارتباط & \\
\hline & 9 & $\wedge$ & $v$ & 7 & المفردة & التصنيف \\
\hline & ${ }^{\bullet} \cdot, 0 \leqslant \varepsilon$ & $\because, \vee \vee \wedge O$ & $\because, 0 . r$ & $" \cdot, \wedge . q$ & معامل الارتباط & \\
\hline $1 \leqslant$ & Tr & ir & 11 & 1. & المفردة & \\
\hline \multirow[t]{3}{*}{$\because \cdot 07}$. & $\because, r V Y$ & "*, Ort & $\because, \varepsilon 17$ & $" \cdot, 91 \pi$ & معامل الارتباط & الجمع و الطرح \\
\hline & 11 & iv & 19 & 10 & المفردة & \\
\hline & $\because$, vo. & 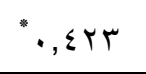 & $\because, v \circ \varepsilon$ & $\because, r 99$ & معامل الارتباط & \\
\hline$r$ & rr & $r$ & $r$. & 19 & المفردة & \\
\hline \multirow[t]{3}{*}{$\because \cdot 07 \mathrm{~V}$} & "ז, & $\because \cdot, \wedge \varepsilon r$ & $\because, \varepsilon \ldots$ & • & معامل الارتباط & العدد ل العد \\
\hline & rv & ru & ro & $r \varepsilon$ & المفردة & \\
\hline & • & $\because, \varepsilon \leqslant 7$ & $\because, T V V$ & $\because, V T r$ & معامل الارتباط & \\
\hline
\end{tabular}

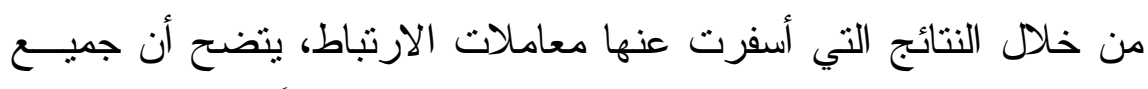

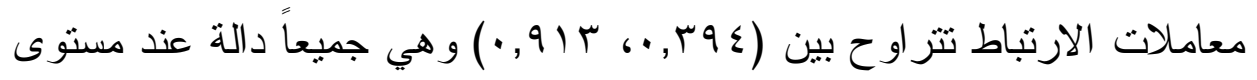

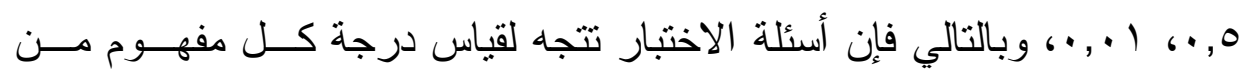

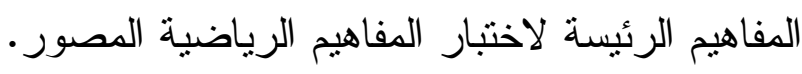


ولتحديد مدى اتساق درجات المفاهيم الرئيسة، و الدرجة الكليــة لاختبــار

المفاهيم الرياضية المصور، تم حساب معاملات الارتباط بين درجة كل مفهـوم رئيسي، و الدرجة الكلية للاختبار، ويوضح الجدول التالي قيم معاملات الارتبــاط بين درجة كل مفهوم رئيسة، و الدرجــة الكليــة لاختبــار المفــاهيم الرياضـــية

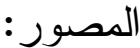

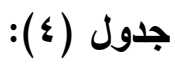

معاملات الارتباط بين درجة كل مهارة رئيسة مع الدرجة الكلية للاختبار.

\begin{tabular}{|c|c|c|}
\hline مستوى الدلالة & معامل الارتباط بالنسبة & المفاهيم الرئيسة لاختبار المفاهيم \\
\hline$\cdot, \cdot 1$ & $" *, 0 . r$ & التصنيف \\
\hline$\cdot, .0$ & " , r १ & الجمع والطرح \\
\hline$\cdot, \cdot 1$ & " •, AOr & العدد \\
\hline
\end{tabular}

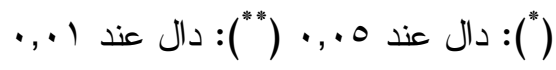

من خلال النتائج التي أسفرت عنها معاملات الارتباط، يتضح أنها جميعـاً

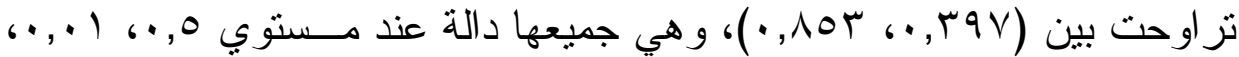
وبذللك يكون اختبار المفاهيم الرياضية المصور مُناسباً للتطبيق علــى مجموعــة

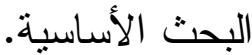

r - حساب الثبات اختبار المفاهيم الرياضية المصور:

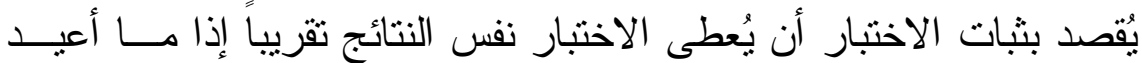
تطبيقه أكثر من مرة على نفس الأفر اد تحت نفس الظروف، وقد تــم اســتخدام طريقة ألفا كرونباخ لحساب معامل الثبات لاختبار المفاهيم الرياضية المــصور، وهي كما يلي: 


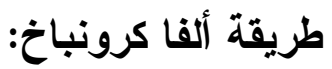

بعد تطبيق اختبار المفاهيم الرياضية المصور علـى مجموعـــة التجربـــة

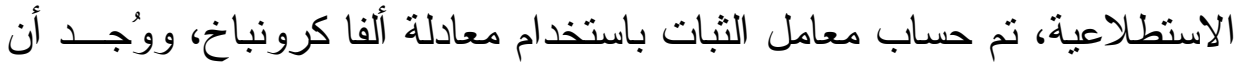

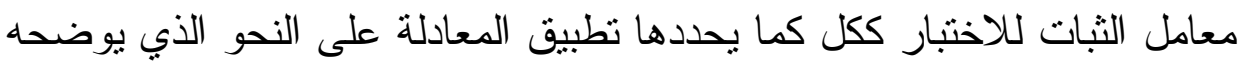

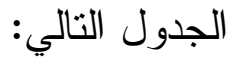

جدول (0)

معامل ثبات (ألفا كرونباخ) لاختبار المفاهيم الرياضية المصور

\begin{tabular}{|c|c|c|c|c|c|}
\hline ألفا كرونباخ & التباين & الاحمراف & المتوسط & العدد & المفاهيم المتضمنة \\
\hline • & $v, 1 r$ & $r, T V$ & A,ro & 9 & التصنيف \\
\hline$\cdot, \times 79$ & $q, r$. & $r, .0$ & $v, r$. & 9 & الجمع والطرح \\
\hline - YYY & $1 \%, 11$ & ri, r & $7, V Y$ & 9 & العدد \\
\hline ת & $\Lambda V, \varepsilon Y$ & Q,ז० & $r,, v r$ & rv & الاختبار ككل \\
\hline
\end{tabular}

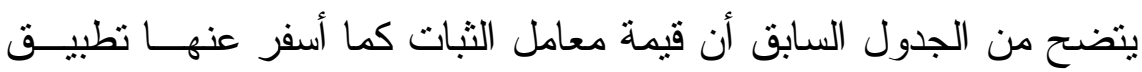

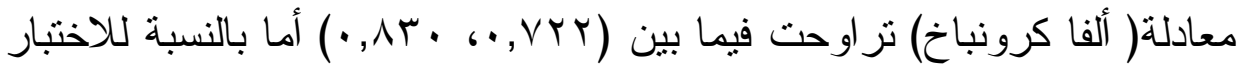

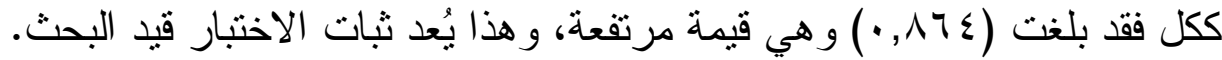
r- تحديد الزمن اللازم لأداء اختبار المفاهيم الرياضية المصور: تم تحديد الزمن اللازم للإجابة عن الاختبار ؛ بتسجيل الزمن الذي استغرقه

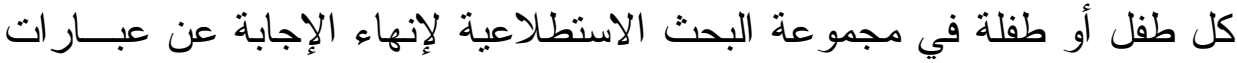
الاختبار ثم حساب منوسط مجمو ع تلك الأزمنة: 


$$
\text { - مجموع الأزمنة = . . } 9 \text { دقيقة. }
$$

- عدد أطفال المجموعة الاستطلاعية = . ب طفل وطفلة.

$$
\text { - زمن إلقاء التعليمات = } 0 \text { دقائق. }
$$

$$
\text { الزمن اللازم للإجابةعن الاختبار= }
$$

يتضح - مما سبق - أن الزمن اللازم لتطبيق اختبار المفاهيم الرياضــية

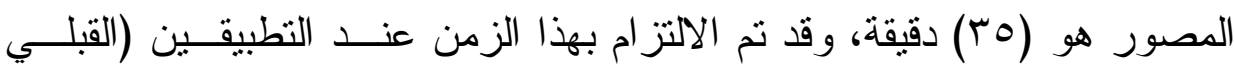

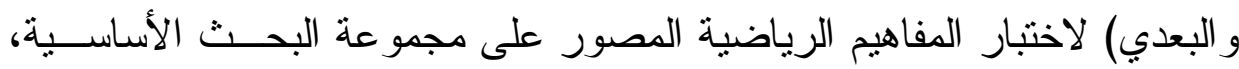

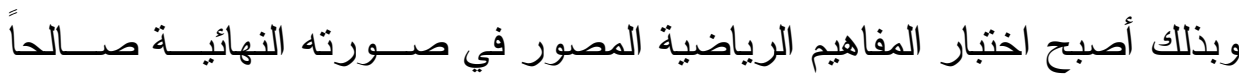
للتطبيق على عينة البحث الأساسية. ثالثاً تطبيق الار اسة التجريبية: 1- الهذف من الاراسة التجريبية للبحث: يتمثل الهدف من الدراسة التجريبية للار اسة الحالية في التعرف على أتثر استخدام إستر اتيجية المشروعات في تتمية المفاهيم الرياضية لدى طفل الروضة. r- منهج البحث المستخدم بالدراسة: اعتمد البحث الحالي على منهجين بحثين هما:

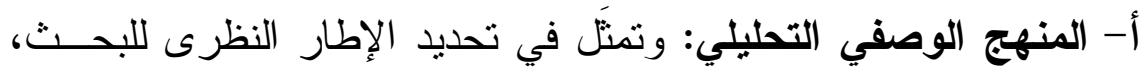

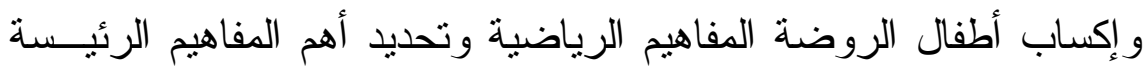

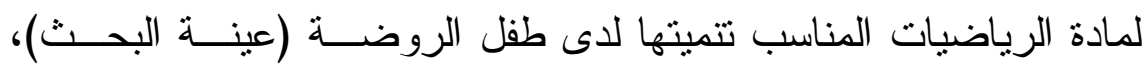
و إعداد اختبار المفاهيم الرياضية. 


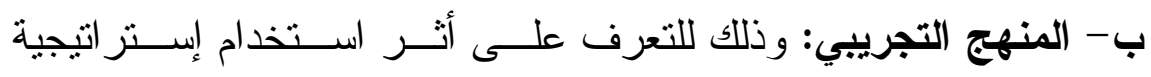

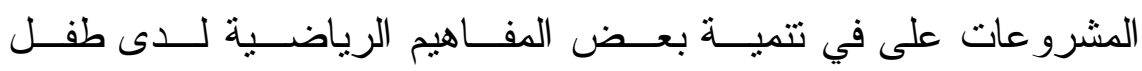
الروضة.

r- متغير ات تجربة البحث وتتحدد في المتغيرات التالية: أ. متفير مستقل: التدريس بإستر اتيجية المشرو عات. ب. متغير تابع: بعض المفاهيم الرياضية لدى طفل الروضة. ؛ - التصميم التجريبي للبحث:

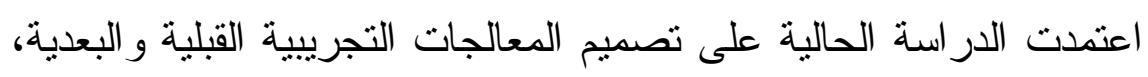

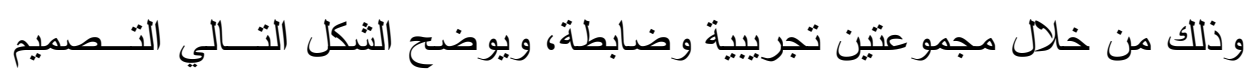

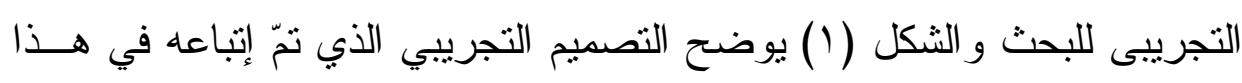
البحث:

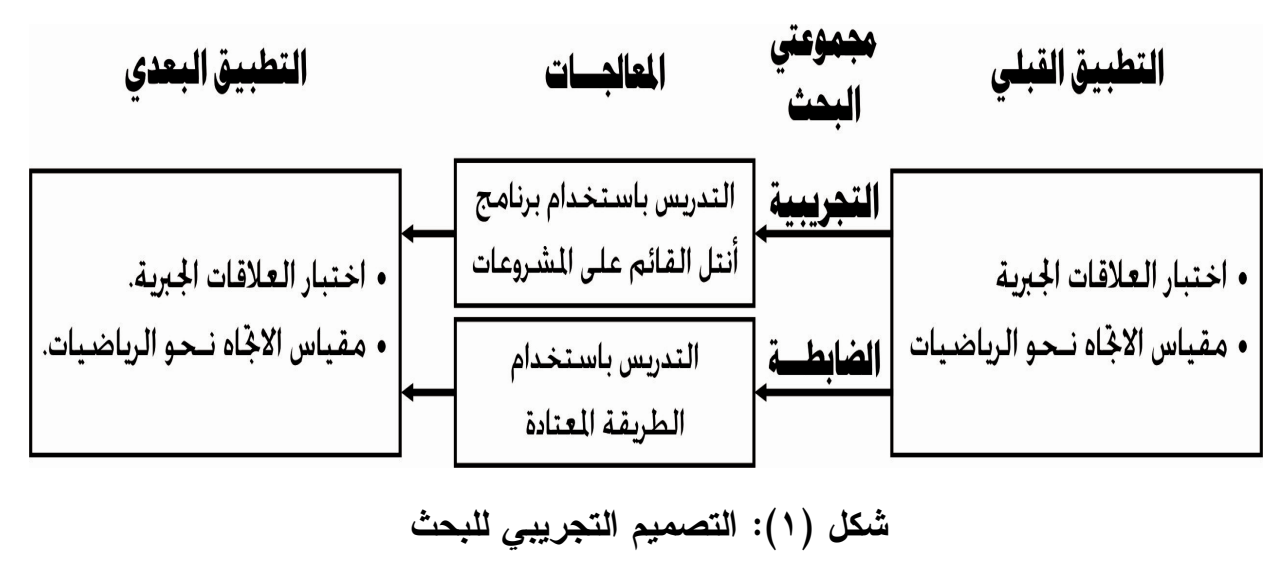

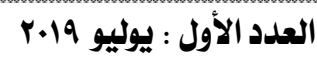
190 المجلد السادس 
ه - اختيار عينة البحث التجريبية:

تم اختيار عينة من أطفال الروضة (المستوى الثاني) بناءً على ما يلي:

• تم اختيار العينة عشو ائياً تمثلت في ( •7) طفل وطفلة من أطفال الروضة

(المستوى الثاني) بروضة المنصورة الرسمية للغات، وروضــة ناصــر

الرسمية للغات بالمنصورة.

• تم تقسيم الأطفال عشو ائياً إلى مجمو عتين، الأولى تجريبية وبلــنغ عـددها ( • (ب) طفل وطفلة بروضة مدر اس المنصورة الرسمية للغات، و الآخــرى ضابطة و عددها ( • (r) طفل وطفلة بروضة ناصر الرسمية للغات.

$$
\text { צ- تطبيق أدوات البحث قبلياً: }
$$

تم تطبيق اختبار المفاهيم الرياضية المصور علــى أطفــال المجمــوعتين

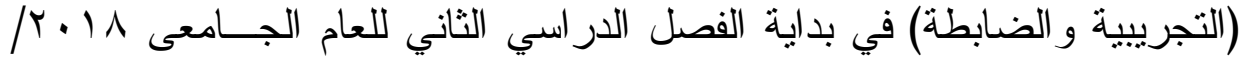
9 1 • rم، بغرض التأكد من تكافؤ وتجانس أطفال عينة البحث، وذللك قبل إجر اء المعالجة التجريبية، وتم استخدام معادلة "ت" لمجموعتين غير مرتبطنتي؛ لبحــث دلالة الفروق بين منتوسطي درجات كل من المجموعة التجريبية و الضـابطة فــي

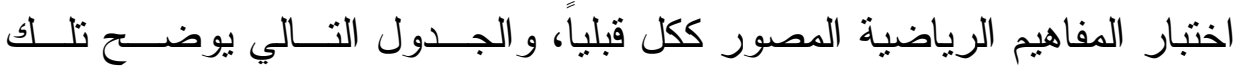




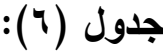

قيمة "ت" ودلالتها الإحصائية للفروق بين متوسطي درجات كل من المجموعتين

التجريبية والضابطة في اختبار المفاهيم الرياضية المصور ككل قبلياً.

\begin{tabular}{|c|c|c|c|c|c|c|c|c|}
\hline مستوى الدلادة & الدلالة & 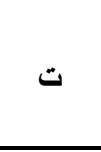 & الحرجية & المعيارى & المتوسط & العدد & مجموعتا & الختبار المفاهيم \\
\hline غير دالة & .14. & , VOA & 01 & $1, V Y$ & 10,10 & $r$. & تجريبية & الاختبار ككل \\
\hline & & & & 1,71 & $1 \varepsilon, \varepsilon V$ & $r$. & ضابطة & \\
\hline
\end{tabular}

يتضح من الجدول السابق عدم وجود فــروق ذو دلالـــة إحـصائية بــين منوسطي درجات المجموعة التجريبية والمجموعة الضابطة في اختبار الدفــاهيم

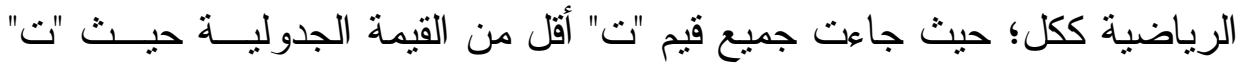

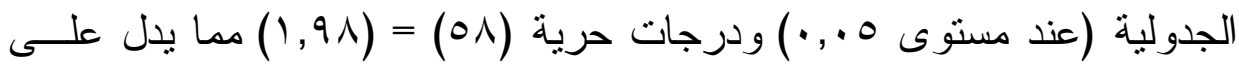
تكافؤ المجموعتن في اختبار الدفاهيم الرياضية المصور القبلي. - V الخطة الزمنية لتطبيق تجربة البحث: - V

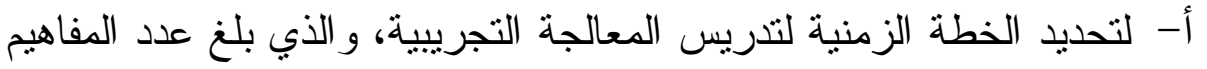

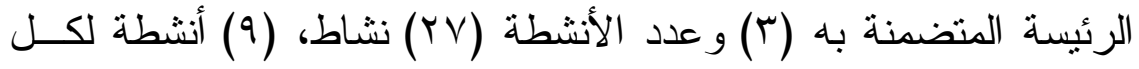

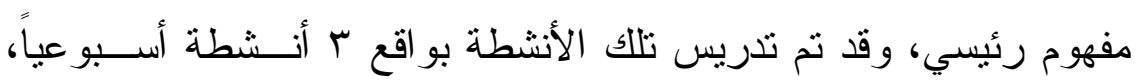

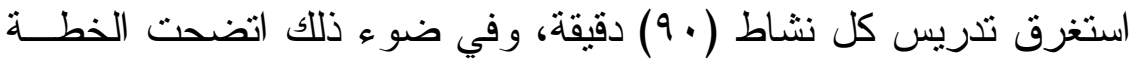
الزمنية لنطبيق تجربة البحث وفق الجدول التالي: 
جدول (v)

الخطة الزمنية لتطبيق البحث

\begin{tabular}{|c|c|c|c|c|}
\hline عدد الأثطة & لكل مفهوم & الأشطة & عدد & \\
\hline الكلية & العدد الع & الجمع والطرح & التصنيف & المجموعة \\
\hline$r v$ & 9 & 9 & 9 & التجريبية \\
\hline
\end{tabular}

1- التطبيق البعدي لأداة البحث:

عقب الانتهاء من التدريس للمجموعتين التجريبية و الضابطة، تم تطبيـق

أداة البحث المتمثلة في اختبار المفاهيم الرياضية المصور بعدياً علــى الأطفــال عينة البحث، وذلك بهدف تحديد الدرجة الكلية البعدية لأداء الأطفال عينة البحث

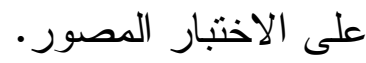

رابعاً: نتائج الدر اسة التجريبية: النتائج الخاصة باختبار المفاهيم الرياضية المصور:

للتحقق من صحة الفرض الأول الذي ينص على "توجد فروق ذو دلاهــة

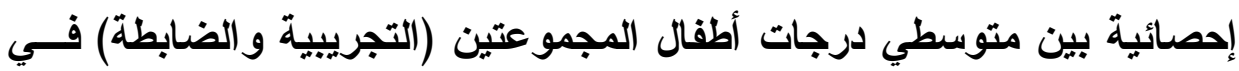

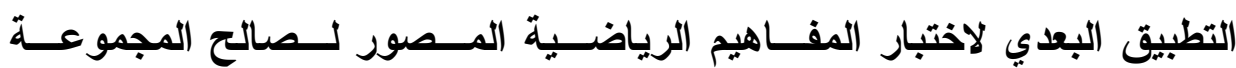
التجريبية".

تم استخدام معادلة "ت" لهجموعتين غير مرتبطتين؛ لبحث دلالة الفـروق

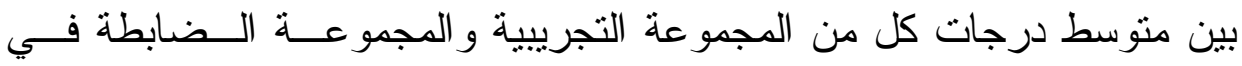
المفاهيم الرئيسة لاختبار المفاهيم الرياضية المصور ككل بعدياً، والجدول التـالي

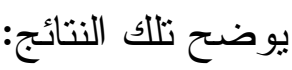




\section{جدول (^)}

قيمة "ت" ودلالتها الإحصائية للفروق بين متوسطي درجات كل من المجموعتين

(التجريبية و الضابطة) في اختبار المفاهيم الرياضية المصور ككل بعدياً.

\begin{tabular}{|c|c|c|c|c|c|c|c|}
\hline مستوى & ت & الدرية & المعيارى الإحر اف & المتوسط & العدد & مجموعتا & الرياضية المصبور المفاهيم \\
\hline دالة & 11,10 & 01 & $r, 0 \wedge$ & $r 0,19$ & $r$. & تجريبية & الاختبار \\
\hline & & & $1, \times 0$ & $\mid v, 1$. & $r$. & ضابطة & ككل \\
\hline
\end{tabular}

يتضح من الجدول السابق وجود فروق ذو دلالة إحصائية بين متوســي ليط

درجات المجموعة التجرييية و المجموعة الضابطة في اختبار الدفاهيم الرياضـــية

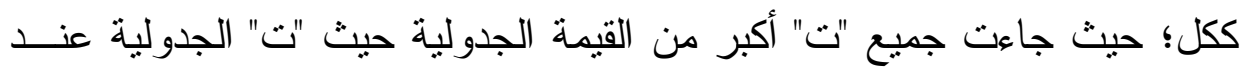

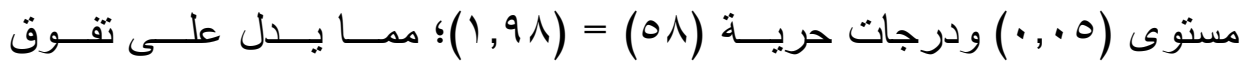
المجموعة التجريبية على المجموعة الضابطة في اختبـار المفــاهيم الرياضـــبة

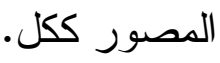

وفي ضوء تلاك النتيجة، يمكن قبول الفرض الأول من فروض البحث وهو

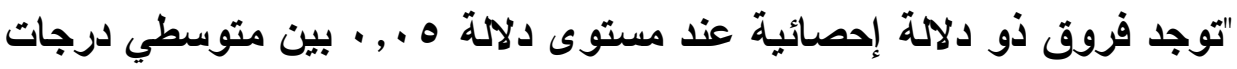
أطفال المجموعتين (التجريبية والضابطة) في التطبيق البعدي لاختبار المفاهيم الرياضية لصالح المجموعة التجريبية". مقارنة نتائج التطبيق القبلي بالبعدي للمجموعة التجريبية في نتـائج اختبـار

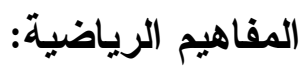

و لاختبار صحة الفرض الثاني الذي ينص على "توجد فــروق ذو دلاهــة

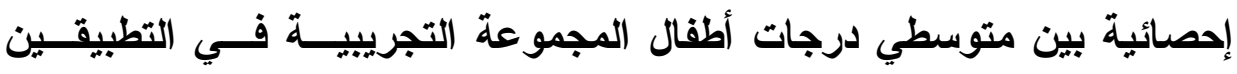
(القبلي و البعدي) لاختبار المفاهيم الرياضية ككل لصالح التطبيق البعدي". 
تم استخدام معادلة "ت" للمجموعات المرتبطة لبحث دلالة الفـروق بـين

متوسطي درجات كل من التطبيقين (القبلي و البعدي) للمجموعة التجريبيــة فـي اختبار المفاهيم الرياضية ككل، و الجدول التالي يوضح تلك النتائج:

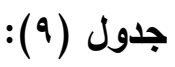

قيمة "ت" ودلالتها الإحصائية للفروق بين متوسطي درجات كل من التطبيقين (القبلي و البعدي) للمجموعة التجريبية في اختبار المفاهيم الرياضية ككل.

\begin{tabular}{|c|c|c|c|c|c|c|c|}
\hline الدلالة & ت & الحرية & المعيارى الإحر & المتوسط & العدد & القياس & الرياضية المصور المفاهيم \\
\hline دالة & $11,1 \mathrm{~V}$ & rq & $r, 0 \wedge$ & Yo, 19 & $r$. & بعدى & الاختبار \\
\hline & & & $1, V Y$ & $10, r_{0}$ & $r$. & قبلى & ككل \\
\hline
\end{tabular}

يتضح من الجدول السابق وجود فروق ذو دلالة إحصائية بين متوســـي درجات التطبيقين (القبلي و البعدي) في المجموعة التجريبية في اختبار المفــاهيم الرياضية ككل؛ حيث جاءت جميع قيم "ت" أكبر من القيمة الجدولية حيــث "ت

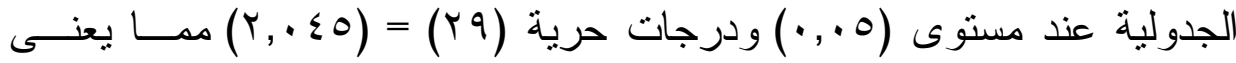
حدوث نمو في اختبار المفاهيم الرياضــية المــصور ككــل لــدى المجموعـــة

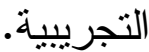
وفي ضوء تلاك النتائج، يمكن قبول الفرض الثاني من فروض البحث وهو "توجد فروق ذو دلالة إحصائية عند مستوى (0 . , • ) بين متوســـي درجـات أطفال المجموعة التجريبية في التطبيقين (القبلي والبعدي) لاختبــار المفــاهيم الرياضية لصالح التطبيق البعدي". 
فاعلية المعالجة التجريبية في تنمية المفاهيم الرياضية (حجم التأثير): لتحديد فاعلية المعالجة التجرييية في تتمية الدفاهيم الرياضــية، و لاختبــار صحة الفرض الثالث من فروض البحث وهو "تحقق المعالجة التجريبية فاعلية

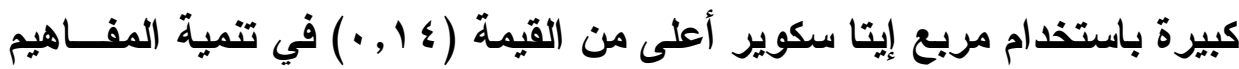
الرياضية ككل ومفاهيمه الرئيسة لاى أطفال مجموعة البحث". تم استخدام معادلة (12) لتحديد حجم تأثثير المعالجة فــي تتميــة اختبــار

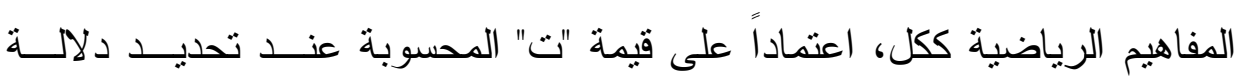

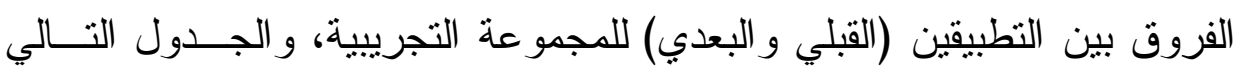

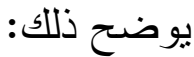

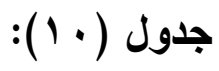

قيمة (ך2) وحجم تأثير المعالجة التجريبية في تنمية المفاهيم

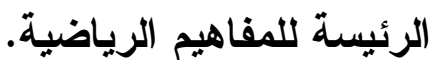

\begin{tabular}{|c|c|c|c|}
\hline حجم التأثير & $\eta^{2}$ & ت & اختبار المفاهيم الرياضية المصور \\
\hline كبير & •, & $11,1 \mathrm{v}$ & الاختبار ككل \\
\hline
\end{tabular}

يتضح من الجدول السابق أن قيمة 2ך لاختبار المفاهيم الرياضــية ككـلـ

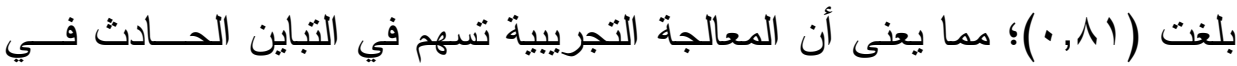
اختبار المفاهيم الرياضية بنسبة (1\%؛، مما يدل على فاعلية المعالجة التجريييــة في تتمية اختبار المفاهيم الرياضية لدى المجموعة التجرييية. 
مناقثة وتفسير النتائج الخاصة باختبار المفاهيم الرياضية المصور: من خلال ما أظهرته النتائج الخاصة باختبار المفاهيم الرياضية المـصصور

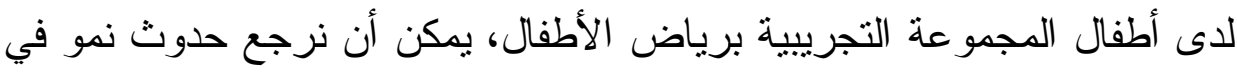

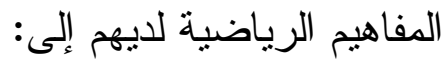

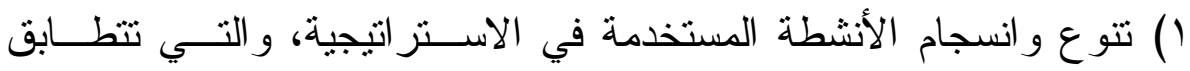
مع كل مفهوم رئيسي من المفاهيم الرئيسة للمفاهيم الرياضـــية المطلـــوبـ

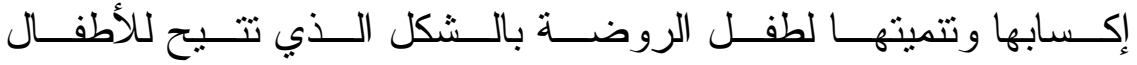
ممارسة المفهوم بالثكل المناسب، و التي تساعد في نمو المفاهيم الرياضية لديهم.

r) جدوى وفاعلية وتتوع الأنشطة المستخدمة فـي الاســتر اتيجية، ويمكـن

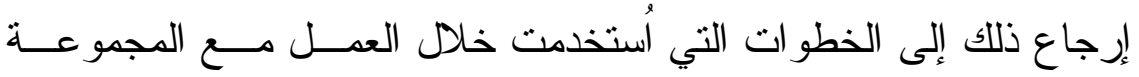
التجرييية "أطفال الروضة" من حيث تكرار الأنثطة يستثير إيجابية الطفل

$$
\text { لاكتساب المفاهيم الرياضية. }
$$

r) طرح الأسئلة المثيرة للتفكير أثناء كل نشاط على الأطفال، وهذه الأســئلة تساعد على إثارة أذهان الأطفال لجذبهم للتعلم، ومن ثم جعل المعلومــات أكثر ثباتاً في أذهانهم، وهذا - بدوره - يؤدي إلى نمو الدهاهيم الهيم الرياضية

$$
\text { لديهم. }
$$

ع) استخدام أساليب التدعيم (التعزيز) سواء أكانت مادية كالجوائز التي توزع

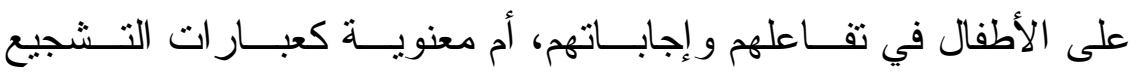
و الاستحسان، التي من شأنها تحفيز الأطفال على التركيز و الاهتمام أثتـــاء

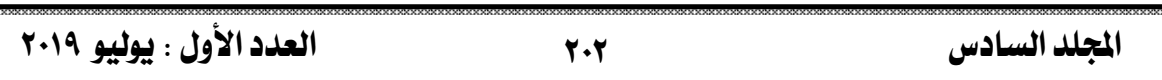


النشاط المتعلق بالمفاهيم الرياضية و المشاركة الإيجابية، ومن ثم ارتفــاع مستوى نمو اكتساب المفاهيم الرياضية لديهر . ملئ. مناقثة وتفسير النتائج الخاصة باختبار المفاهيم الرياضية المصور: وتتفق نتائج البحث مع در اسة كلٌ من:

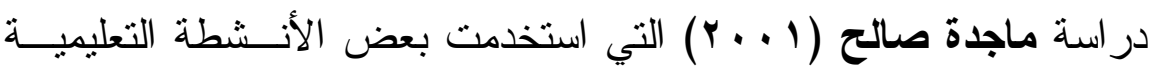
لتتمية الحس العددى لدى طفل ما قبل الددرســة، ودراســة ربــاب الــشافعي

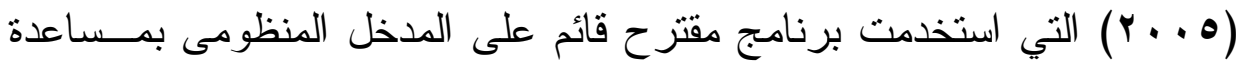

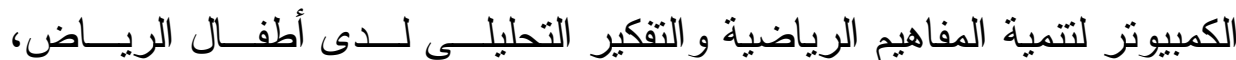

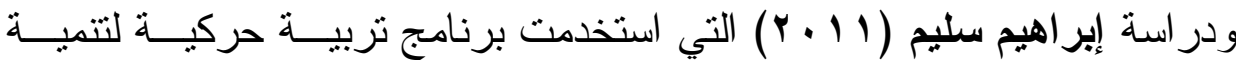

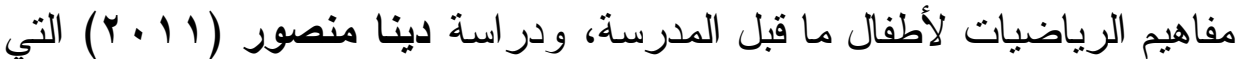

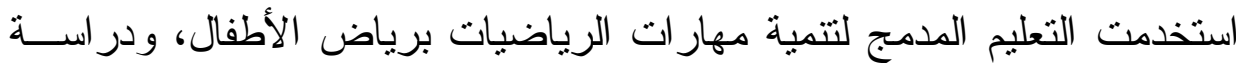

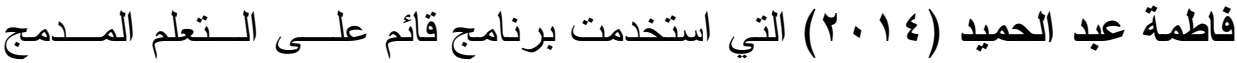

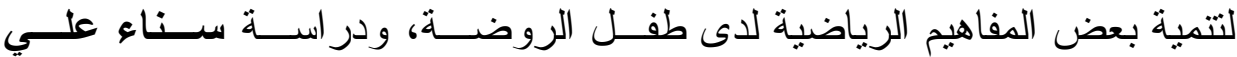
التي استخدمت برنامج محوسب لتتمية بعض المفاهيم الرياضية لــدى (Y V V)

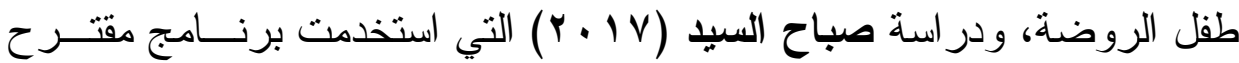
قائم على استخدام القصص الرقية لتتمية بعض الدفــاهيم الرياضــية و التفكيــر

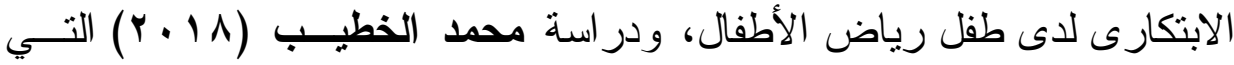
استخدمت الدر اما التعليمية لإكساب المفاهيم الرياضية و العلميــة لــدى أطفــال

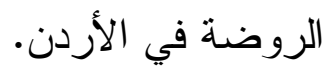

r.19 المجلد السادس




\section{سادساً توصيات البحث:}

في ضو ء ما أسفرت عنه نتائج الدر اسة، توصي الباحثة بما يلي:

(أ) توصيات خاصة بالمسئولين عن رياض الأطفال وتثمل ما يلي:

1. عقد دورات تدرييية لمعلمات رياض الأطفال تتتاول ماهيــة إبــنر اتيجية

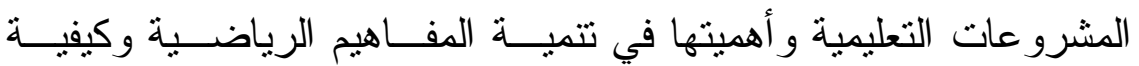

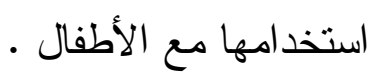

r. إعداد دليل لمعلمة رياض الأطفال، و الذي يساعدها على كيفية اسـتخدام

$$
\text { إستر اتيجية المشرو عات بطريقة صحيحة. }
$$

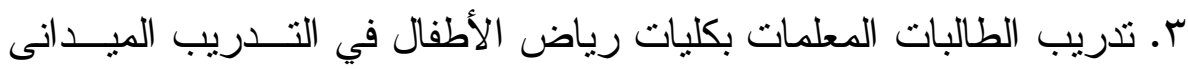

على كيفية استخدام إستر اتيجية المشرو عات بطريقة صحيحة.

(ب) توصيات خاصة بمعلمات رياض الأطفال وتثمل ما يلي:

ا. القر اءة الجيدة عن إستر اتيجية المـشروعات بــصفة عامــة و الدفــاهيم

الرياضية التي تساعد طفل الروضة على التكيف و التو افق مع البيئة وفهم

مادة الرياضيات بصفة خاصة.

r. إعداد بر امج تتقفية من خلال البرامج التدريبية المختلفة حـــل القـدرات

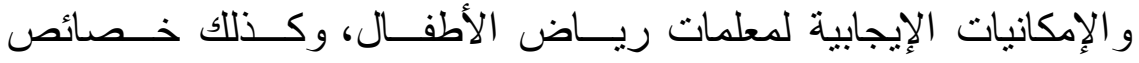

منطلبات مرحلة رياض الأطفال. 


\section{سابعاً الار اسات و البحوث المقترحة:}

دراسة أثر استخدام إستر اتيجية المـشروعات علـى تتميــة المهــارات الاجتماعية ومتعة التعلم لاى طفل الروضة.

• دراسة أثر استخدام إستر اتيجية المشروعات على تتمية مهار ات التقكيـر

المختلفة لدى طفل الروضة.

• إجر اء المزيد من الدراسات التي تتتاول فاعلية إستر اتيجية المـشروعات،

وفي تتمية جو انب أخرى للتعلم لاى أطفال الروضة.

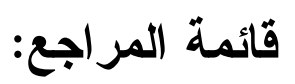

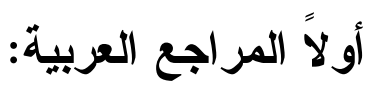

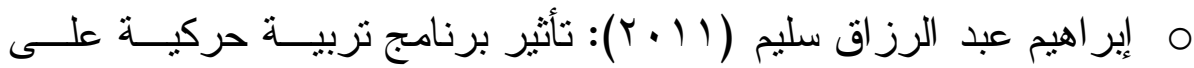

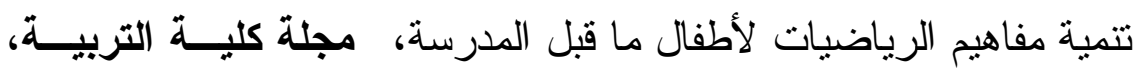

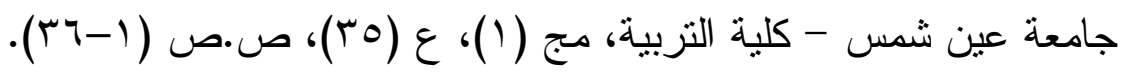

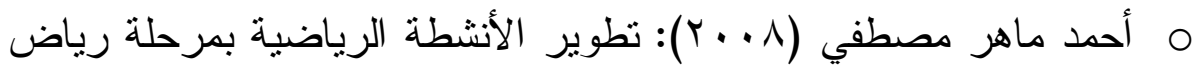
الأطفال في ضوء متطلبات معايير الرياضيات المعاصرة، رسالة دكتور اه اه غير منشورة، كلية التربية بشبين الكوم، جامعة المنوفية.

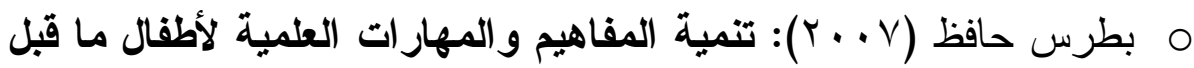
المدرسة، عمان: دار المسيرة للطباعة و النشر •

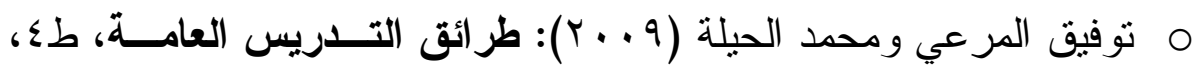
دار المسيرة للنشر و النوزيع: عمان. 


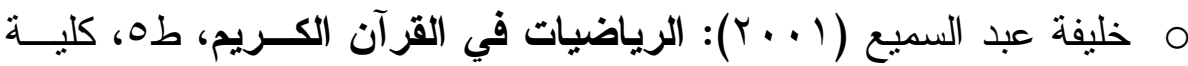

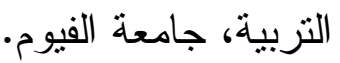
O دينا منصور عبد الفتاح (11 + r): فاعلية استخدام التعليم المدمج في تتمية مهار ات الرياضيات برياض الأطفال، رسالة ماجسـتير غيــر منسشورة، معهد الدراسات و البحوث التربوية، جامعة القاهرة.

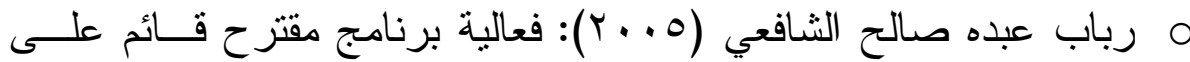

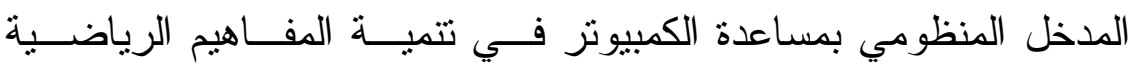
و التقكير التحليلى لدى أطفال الرياض.رسالة ماجستير غيـر منـشـورة، كلية التربية النوعية ببورسعيد، جامعة قناة السويس.

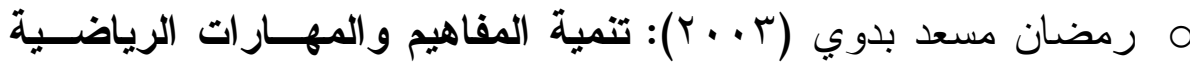
لأطفال ما قبل المدرسة، دار الفكر : عمان.

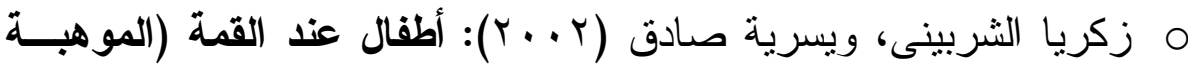
والتفوق العقلي والإبداع)، دار الفكر العربي، القاهرة.

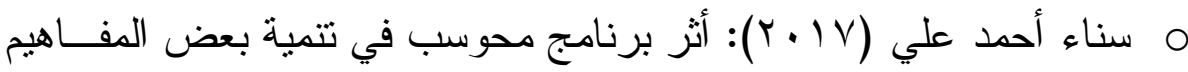

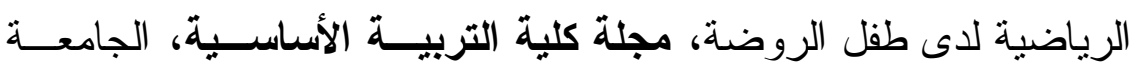

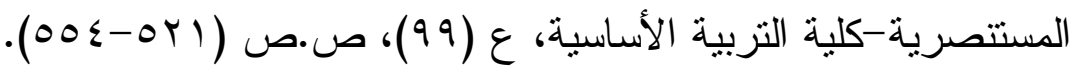

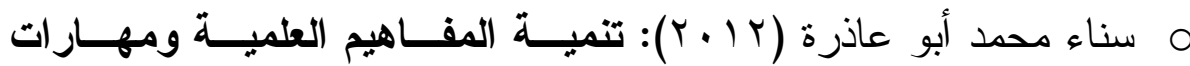
عمليات العلم، دار الثقافة للنشر و التوزيع: عمان.

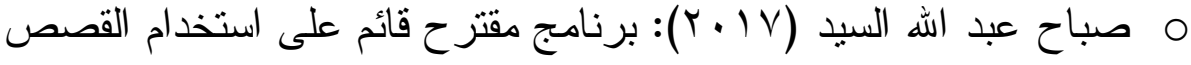

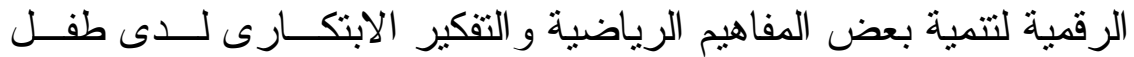


رياض الأطفال، مجلة دراسات عربية في التربية وعلم النفس، رابطـــة

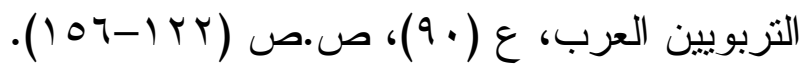

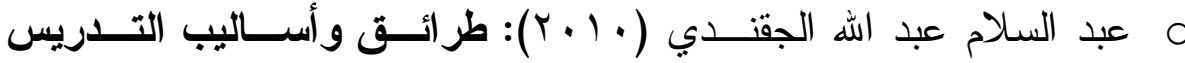
المعاصرة ... دليل المعلم العصري في التربية وطرق التدريس، عمــان،

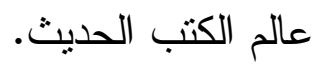

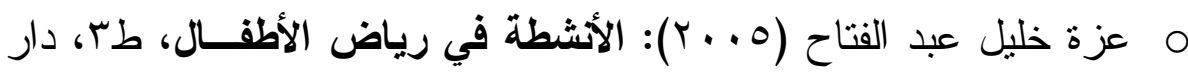

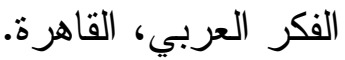

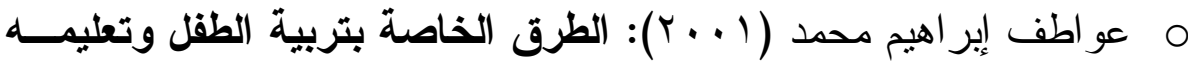
في الروضة، مكتبة الانجلو المصرية: القاهرة. م فاطمة السيد عبد الحميد (؟ ب ب): برنامج قائم على التعلم المدمج لتتميــة بعض الدفاهيم الرياضية لاى طفل الروضة، مجلة تربويات الرياضـيات،

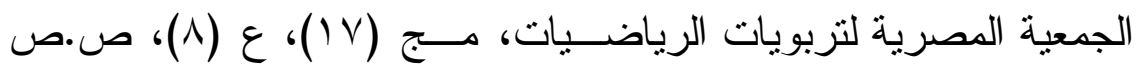
$\cdot(r \leq-r \mid q)$

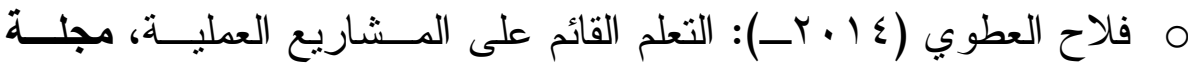
المعرفة الإكترونية، متاحة على الموقع: http://www.almarefh.net.

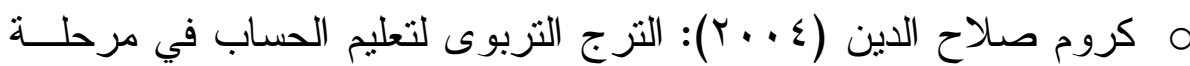

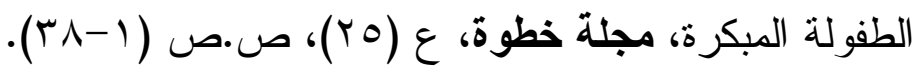

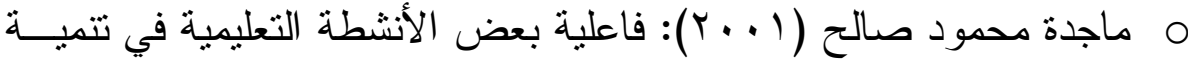
الحس العددي لاى طفل ما قبل المدرسة، مجلة القراعة والمعرفة (مجلـــة

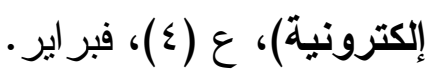




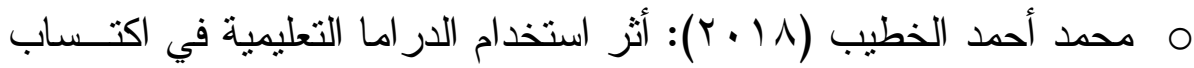

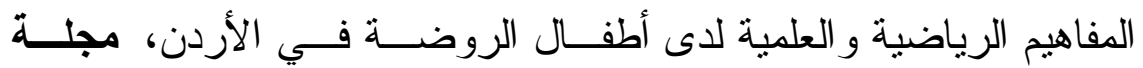

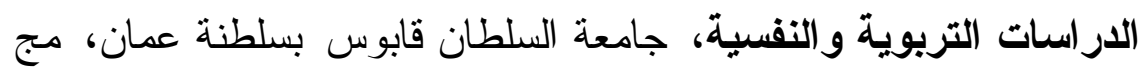

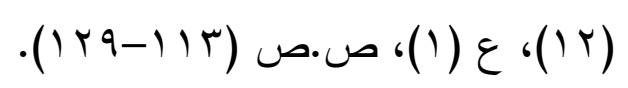

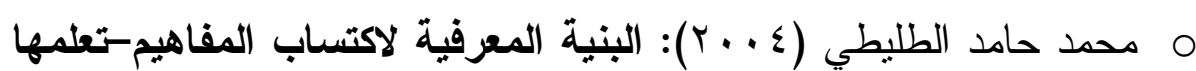
وتعليمها، دار الأمل للنشر و التوزيع: عمان.

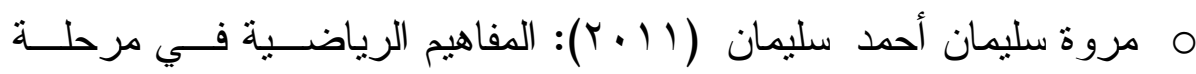

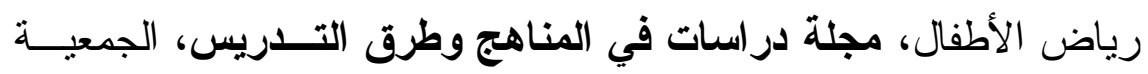

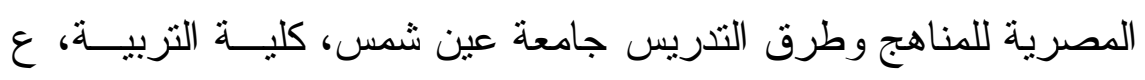

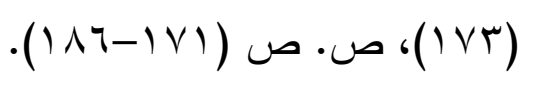

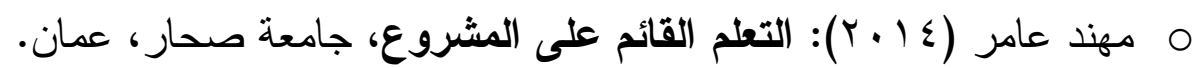

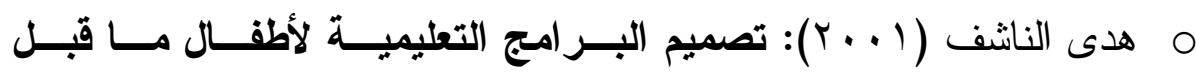
المدرسة، دار الكتاب الحديث: القاهرة.

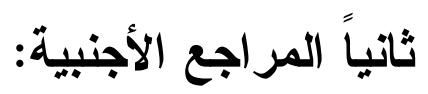

○ Bertrand, J., (2007): "Early Learning for Every Child Today A framework for Ontario early childhood settings". Ontario Day. Canada.

○ Creech, N. \& Bhavnaari, N. (2002). "Teaching elements of story through drama to 1 grader: child development 
frameworks": Childhood Education, Vol. (74), No. (4), P.P. (219-225).

○ Clements, S. (2006). "Building math through every day". Journal Articles, Opinion Papers Reports, Vol. (19), P.P. (50-57).

○ Fleming, M., Merrell, C. \& Tymms P. (2004). "The impact of drama on pupils'language, mathematics, and attitude in two primary schools". Research Drama Education, Vol. 9, No. (2), P.P. (177-197).

- Soydan, S. \& Quadir, S. (2013). "Observation of the effectiveness of drama method in helping to acquire the addition- subtraction skills by children at preschool phase". Educational Research and Reviews, Vol. (8), No. (18), P.P. (1689-1697).

○ Wegner. C., Minnaert. L. and Strehlke. F., (2013): “The importance of learning strategies and how the project Kolumbus-Kids' promotes them successfully". European Journal of Science and Mathematics Education Vol. (1), No. (3), P.P. (137-143). 